\title{
State-led Forced Migration in the Canadian Context: A Look into Canada's Deportation Flights
}

\section{by}

\author{
Leslie Andrea Muñoz
}

A thesis submitted to the Faculty of Graduate and Postdoctoral Affairs in partial fulfillment of the requirements for the degree of

\author{
Master of Arts
}

in

Political Economy

Carleton University

Ottawa, Ontario

(C) 2016, Leslie Andrea Muñoz 


\begin{abstract}
This thesis contributes to existing literature on deportation in Canada by providing a viapolitical analysis of how removals are realized in the settler-colonial Canadian context. Using empirical evidence obtained through access to information requests, media sources, activists and from select corporate documents produced by the Canada Border Services Agency and other actors, I argue that the wide-scale incorporation of airplane technology in contemporary deportation regimes has fundamentally reconfigured the way in which present-day expulsions are realized with the effect of partially sanitizing and legitimizing what was once considered a severe, often lethal penal practice comparable to the death penalty. For this reason, it can be said that seemingly benign aircrafts not only facilitate regular migration flows, they also double as politically-charged sites implicated in the violence of coercive expulsion. While the majority of removal practices are commonly, if only tacitly, accepted by the general public, others challenge the assumption that states always abide by the law. The normalization of 'air deportation' has also led to the emergence of new actors in removal operations: some are unwilling participants while others are driven by profit-incentives, enabling us to speak of the emergence of a distinct Canadian 'migration control industry' profiting from the business of air deportation. Migrants, their allies and a number of other affected actors have nonetheless developed innovative tactics to resist and dialectically reshape contemporary expulsions. Many of these acts of contestation target the very specificities and vulnerabilities of the deportation flight.
\end{abstract}




\begin{abstract}
Acknowledgements
This thesis would not have been possible without the contributions of numerous individuals and organizations who lent me their support over the past two years. I'm particularly grateful for the work of my supervisor, William Walters, whose valuable insights helped to shape the direction of this thesis and who also provided me with a number of exciting opportunities throughout the course of my MA. It is also important that I acknowledge the support of Donna Coghill, Cristina Rojas and Laura MacDonald, who enriched my experience at Carleton University's Institute of Political Economy and were always willing to answer the million questions I had for them on any given day. Deep thanks to my good friend Sarah Phinney and lovely partner Kristen Bonnell for proofreading earlier iterations of this thesis and for their constant encouragement and feedback. I would also like to thank everyone in my community, particularly my family and friends, for informing my perspectives and for unconditionally supporting me every step of the way. Finally, I'd like to thank the Social Sciences and Humanities Research Council and the Borders in Globalization Project for supporting the realization of this research.
\end{abstract}




\section{Table of Contents}

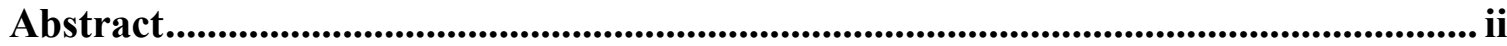

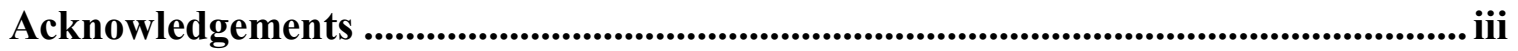

Table of Contents ................................................................................................................ iv

List of Figures...................................................................................................v v

Chapter 1: Deportations Flights in Canada: Context, Theory and Methodology ...... 1

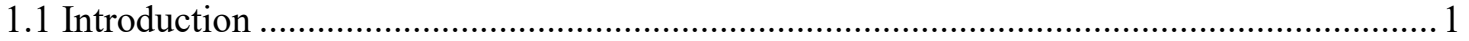

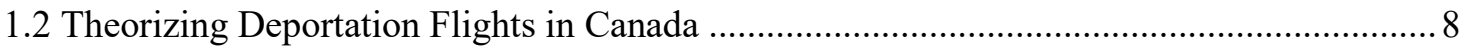

1.2.1 Viapolitics, Mobility in Carceral Practices and Contemporary Expulsion .................... 8

1.2.2 Foucauldian Analytics and the Deportation Flight.................................................... 10

1.2.3 The Rise of the Settler Colonial Canadian State and Deportation .............................. 17

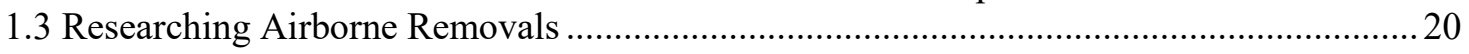

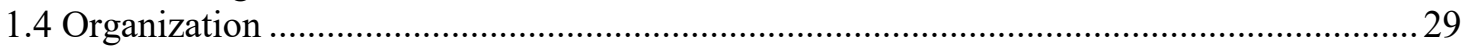

Chapter 2: Antecedents to Contemporary Removals in Canada: A Viapolitical

Analysis of Selected Literature on Past Expulsions................................................... 31

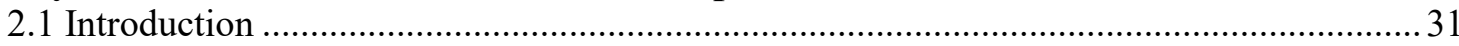

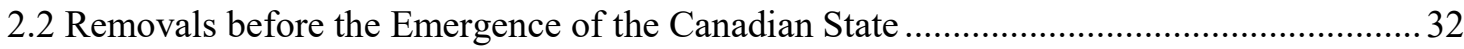

2.3 Rail and Steamship-based Deportation post-Confederation........................................... 43

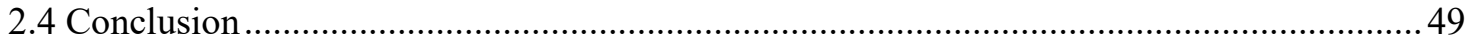

Chapter 3: Contemporary Removals in the Canadian Context and the

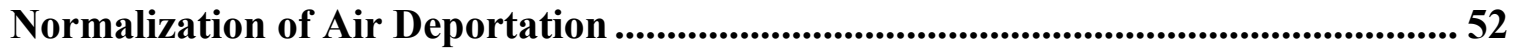

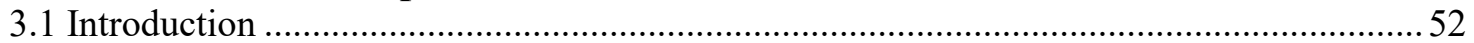

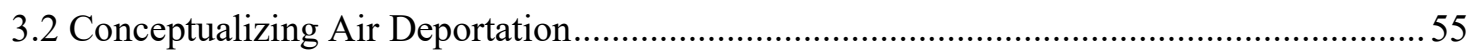

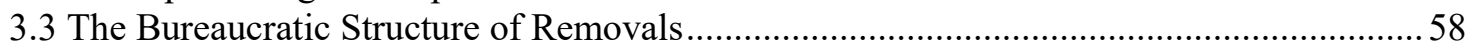

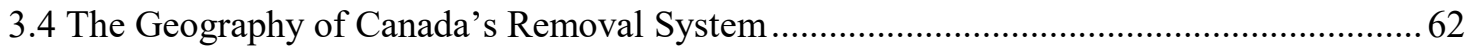

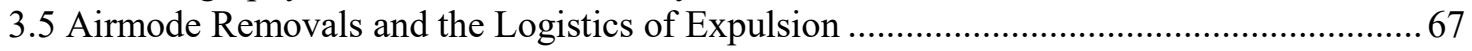

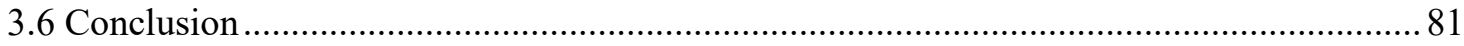

Chapter 4: The Political Economy of Deportation in Canada: 'Doing more with less'

and the Canadian Migration Control Industry ............................................................. 82

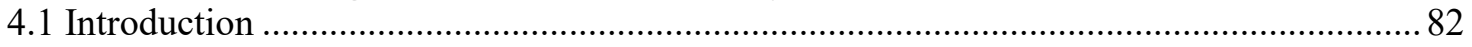

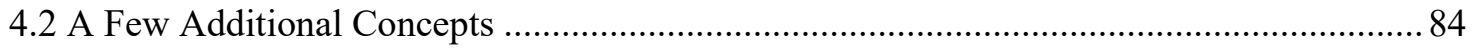

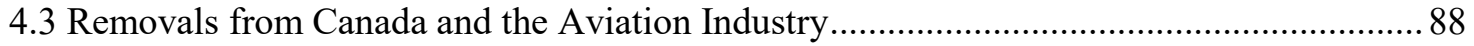

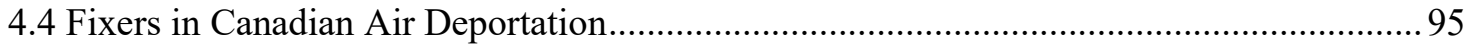

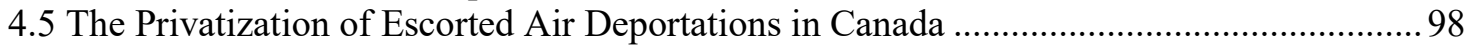

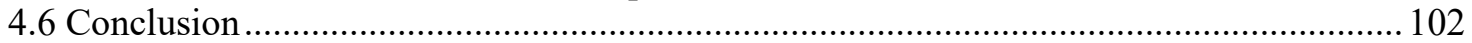

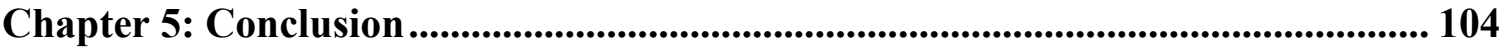

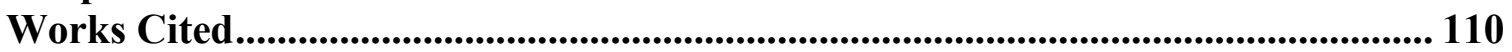




\section{List of Figures}

Figure 1 — Number of Deportations from Canada by FY 2002/2003-2013/2014........... 4

Figure 2 — Saeed Jama's Removal Passage ............................................................ 9

Figure 3 - Griffith's mapping of the Expulsion of the Acadians ............................... 36

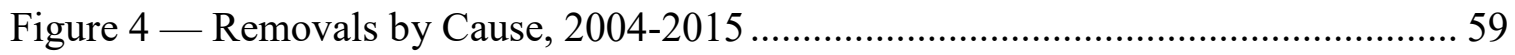

Figure 5 - Evas Airlines Interregional Deportation Flight, 12 January 2008 ............... 66

Figure 6 -Top 15 Escorted Removal Nationalities 2004-2014 ............................... 70

Figure 7 - Canadian Immigration Enforcement and Refugee Program Expenditures ... 83

Figure 8 - Yassin Ibrahim's Deportation Passage .............................................. 93 


\section{Chapter 1: Deportations Flights in Canada: Context, Theory and Methodology}

\subsection{Introduction}

Saeed Ibrahim Jama's deportation from Canada began on the $26^{\text {th }}$ of November, 2012. He was boarded onto the first leg of his removal in handcuffs and would travel alongside the four Canadian escorts responsible for enforcing his expulsion as he transited through Calgary, Amsterdam and then Nairobi. In Nairobi, the stateless SaudiArabian born child of Somalian refugees was handed over by the Canada Border Services Agency (CBSA) to Kenyan officials alongside a payment of $\$ 25,000$ in cash. Jama was then transported by a small regional airline called African Express to the Somalian capital of Mogadishu where he was met by an airport worker paid by Kenyan officials to smuggle Jama past security so that his deportation passage from Canada could be finalized (Chipman, 2015 and Zilio, 2013). His Canadian escorts had excused themselves from this final portion of the removal since Somalia is considered too dangerous for public servants.

In that months that followed, a number of news articles would be published documenting the unusual circumstances surrounding Jama's removal. Not only did they highlight the peculiarities of his expulsion, they also questioned why Jama, who had arrived to Canada as a child, had been removed to a failed-state that he had never visited and where he did not speak the language. Then came a radio documentary from the $C B C$ discussing what had happened to Jama after he was smuggled into Somalia. Shortly after his deportation, Jama was kidnapped by a gang and held captive until his Edmontonbased parents paid a ransom for his release (Chipman, 2015). The report critiqued the CBSA's failure to hold itself accountable for the wellbeing of those it removed from the 
country and while doing so also shed light on the mechanics of contemporary expulsions, including the modalities of transportation and types of transnational partnerships necessary to maintain a deportation regime.

Although high-profile and controversial expulsions such as Jama's are occasionally covered in the news, most removals from Canada take place in closed contexts far from the public gaze. Jama's removal story, albeit exceptional, therefore provides a rare glimpse of state-led forced migration in Canada, a practice that uses airplanes and the existing civil aviation transportation system to quietly expel thousands of 'unwanted' individuals from the settler-colonial Canadian territory in any given year. ${ }^{1}$ These deportation flights, and the socio-political and economic systems upon which they rely, are the focal point of this thesis, which aims to contribute a critical study of deportation in Canada in order to expose removals as a drastic policy option while also highlighting the significant humanitarian concerns surrounding the wide-scale legitimation of contemporary banishment without regard for migrants' freedom of movement, established livelihoods and affective ties to Canada.

Throughout this thesis, I have adopted a viapolitical lens in order to focus on the mechanisms of transportation that enable deportations to occur. Walters describes 'viapolitics' as a particular angle of inquiry, one which enriches familiar debates on migration and politics by highlighting the role of vehicles, routes, and systems of transportation within migration phenomena such as deportation (2014). In doing so, this tactical shift encourages a consideration of the ways in which "migratory struggles play

\footnotetext{
1 I refer to Canada as a settler-colonial entity due to its ongoing history as a nation-state founded and maintained on colonized indigenous lands. For more readings on Canadian settler-colonialism, see Coulthard, 2008 and Taiaiake and Corntassel, 2005.
} 
out not just in fixed settings and structures but in and around vehicles" and the infrastructures through which they navigate (Walters, 2014). Such an approach is useful because of the insights it affords on the way the work of deportation is carried out in places such as Canada. For example, when removal practices are considered through the lens of viapolitics, the airplane emerges as more than just a background detail of contemporary expulsion and instead becomes visible as a crucial, politicized-site of force and contestation constitutive of the deportation passage - an in-between space deserving of further inquiry.

My interest in discussing contemporary expulsions in Canada from the viapolitical vantage point of the deportation flights used to enforce them is threefold. Firstly, there has been a significant surge in the number of removals carried out by Canadian immigration enforcement officials since 9/11 and the subsequent establishment of the CBSA in late 2003. This phenomena has received scarce academic attention, ${ }^{2}$ possibly on account of how small-scale the Canadian deportation apparatus appears when compared to the size of other deportation systems such as those operated by the United States (US), the United Kingdom (UK) and a number of other countries. Canada's removal levels are nonetheless significant: between 2004 and 2015, 156,341 migrants were expelled from Canadian territory and 70\% of these individuals were asylum seekers (CBSA, 2015a).

At the system's peak in fiscal year 2012/2013, 18,946 migrants were discretely funneled out of the country bound for destinations around the globe (CBSA, 2015b). To put this figure into perspective, in 2002/2003 the enforcement branch of Citizenship and

\footnotetext{
${ }^{2}$ For notable exceptions, see Pratt, 2005 and Walia, 2013.
} 
Immigration Canada (CIC) removed only 8,683 individuals from Canadian territory (CBSA, 2015b). Deportations therefore increased by 118\% in the first ten fiscal years of the CBSA (see Figure 1).

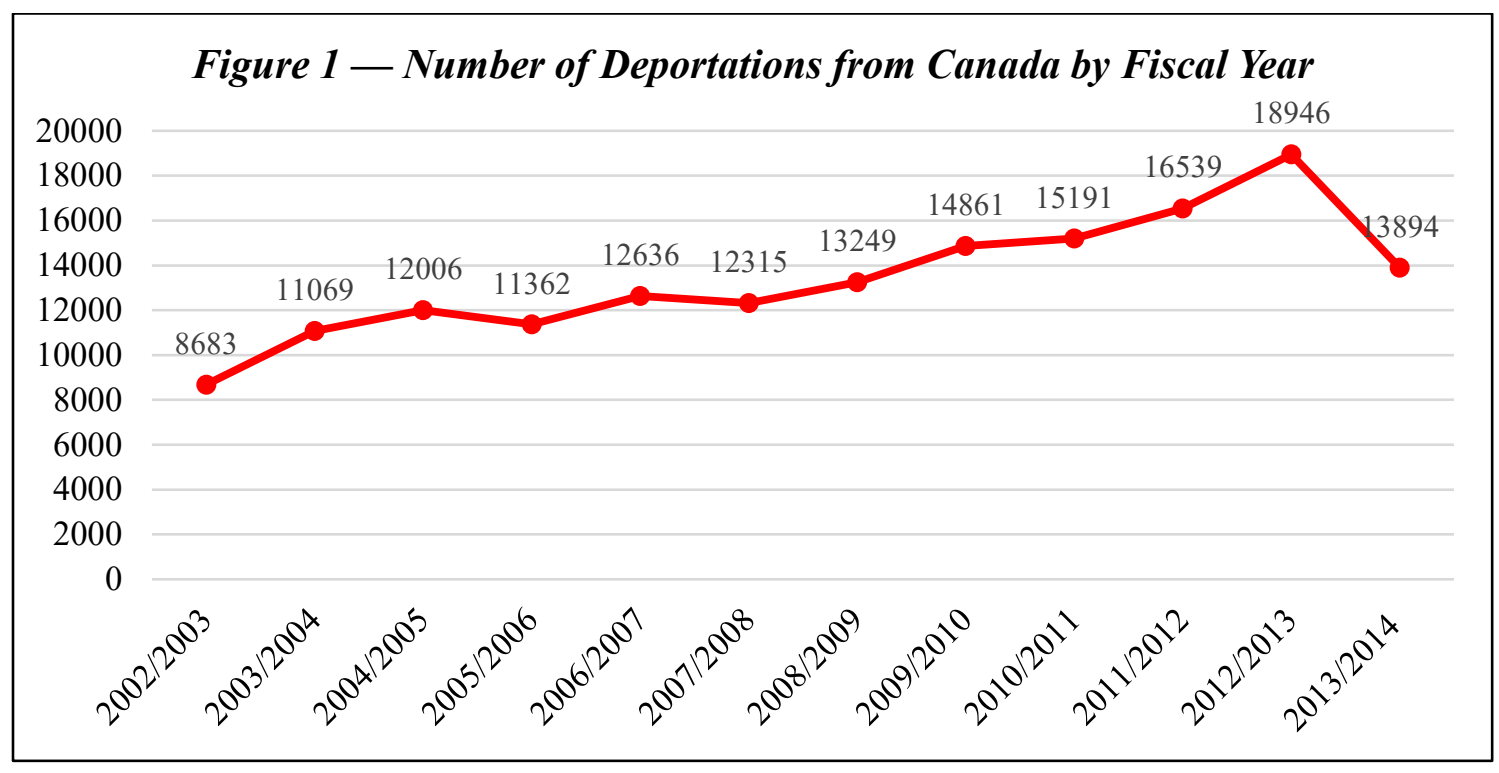

Figure 1 - Number of Deportations from Canada by Fiscal Year 2002/2003 - 2013/2014 (CBSA, 2015b)

Given these trends, a 'Canadianized' study of deportation and its associated vehicles of expulsion is timely in order to establish a comprehensive understanding of present-day removals. Although deportation levels have declined since 2012/2013 (Black, 2015), it is critical that we consider the fiscal and logistical arrangements, technological requirements and sheer human effort enabling the rapid growth in expulsions that occurred as a consequence of border-related over-securitization in Canada post-9/11.

Second, studying the mechanics of the deportation passage is critical because it is indicative of how removals have changed over time, not just logistically but also in terms of how they are perceived by the public. Referring to the comparable American example, De Genova states that, "at the beginning of the twentieth century, it was commonly considered to be frankly unconscionable, even by some immigration judges, to inflict the 
plainly punitive, 'barbarous and cruel' hardship of expulsion on unauthorized but otherwise lawful long-term migrants and their families" (De Genova, 2010). Yet in the twentieth-first century, practices of expulsion abound and exist as highly normalized procedures routinely enforced by territorially defined nation-states around the world, thus contributing to what Peutz and De Genova refers to as a 'global deportation regime'(2010).

It is my contention throughout this thesis that the rise of what Walters terms 'air deportation' has played a critical role in the legitimation of these modern-day removals (Walters, 2016a). I argue that the aircraft, which serves as the primary vehicular technology used to carry out deportations, has fundamentally reconfigured the way in which contemporary expulsions are realized with the effect of sanitizing what was once considered a severe, often lethal penal practice comparable to the death penalty. ${ }^{34}$ For this reason, it can be said that seemingly benign passenger airplanes forming part of the international civil aviation system not only facilitate regular migration flows, they also double as politically-charged sites implicated in the violence of coercive expulsion. These in-between, extraterritorial spaces commonly associated to free movement therefore play a strategic role in the work of deportation because they function as critical components of the infrastructure of removal. While research has been conducted on deportation flights in Europe by scholars such as Walters (2014 and 2016a), Fekete (2011), and migrant justice groups such as Corporate Watch in the UK (Miller and Shiar, 2013) and Campaña

\footnotetext{
${ }^{3}$ Walters has described prisoner transportation, a practice of the British Empire in which prisoners sentenced to the death penalty could appeal to the crown for mercy and instead be banished overseas, as a key antecedent to deportation, hence the likening of contemporary expulsion to the death penalty in this thesis (2010).

${ }^{4}$ On a more theoretical note, deportation has also been described by Barker as a form of 'civic death' since "the state effectively cuts off all ties, connection and any obligation to the person" being removed (2013).
} 
Estatal por el Cierre de los Centros de Internamiento de Extranjeros (CECCIE) in Spain (2014), deportation flights in the Canadian context remain unstudied - a gap in knowledge which this research aims to fill.

Lastly, this study is driven by an interest in the political economy of deportation, specifically the expansion of public-private partnerships or what Gammeltoft-Hansen has termed the 'migration control industry' in the realm of airborne removals carried out by the Canadian-state (2013). As Walters notes, "deportation is business" and should be seen as more than just a procedure carried out by nation-states exercising powers of policing and state-sovereignty (2010). Beyond police officers and immigration authorities, the work of deportation in Canada and elsewhere also involves for-hire personnel, "airline executives, pilots, stewards and other passengers" (Walters, 2010). While some of these actors may be unwilling or unknowing participants in a migrant's deportation passage, others are driven by profit-incentives and therefore benefit from removing bodies on behalf of or in partnership with the CBSA.

Woven throughout this thesis are also numerous anecdotal accounts of antideportation resistance and other moments of contestation. These stories evidence the diverse ways in which practices of expulsion are resisted, not only by migrants and their allies, but also transportation companies, immigration enforcement workers, transit countries and receiving states. Wright (2013), Walia (2013), De Genova (2010), Fortier (2013), and Walters (2010), amongst many others, have argued that immigration enforcement practices are constantly challenged and dialectically reshaped in response to anti-deportation activism and other forms of resistance. I contribute to this critical literature from a viapolitical standpoint focused on providing Canadian examples that 
highlight the new and innovative tactics of resistance that have emerged worldwide targeting the specific contingencies and vulnerabilities of the airborne removals of the Jet Age.

Before moving forward with the theoretical and methodological sections of this introductory chapter it is important that I make a few notes on semantics. Firstly, throughout this thesis I use the term 'deportation' to refer to all practices of contemporary immigration-related expulsion in Canada, regardless of whether or not these removals are enforced using 'deportation orders' or other, differently-named bureaucratic categories of expulsion (i.e. withdrawn applications for admission [also known as same-day removals], departure orders, etc.). Second, I adhere to the notion that no one is 'illegal' and therefore stress throughout this thesis that 'illegality' is not an inherent condition, instead, migrants are 'illegalized' and rendered deportable through state mechanisms (Peutz and De Genova, 2010).

Finally, I commonly though not exclusively, use the term 'migrants' as a catchall term to refer to all persons rendered deportable who have migratory relationships to the Canadian landscape, be they permanent residents, visa over-stayers, categorical refugees, or asylum seekers. I do this acknowledging that the term 'migrant' is commonly used to invalidate and delegitimize the status of refugees (Bauder, 2013). I nonetheless prefer this term since it is more inclusive and because I accept the assumption that all migrants are deserving of mobility rights as well as the right to remain, not just economic class immigrants, family sponsorship immigrants, protected persons and convention refugees. 
This introductory chapter will now turn to a discussion of theory and methodology before concluding with a few words outlining the remainder of this thesis.

\subsection{Theorizing Deportation Flights in Canada}

To theorize deportation flights in Canada, I draw from Walters' notion of 'viapolitics' in conjunction with Foucauldian understandings of deportation. The use of a viapolitical approach in this research is useful in order to focus on the dynamics of the deportation flight, in other words, on the modalities of transportation with which removals are realized. I include the use of Foucauldian forms of power in my theoretical framework on account of their explanatory ability to enhance understandings of removals and expulsions more broadly. My theoretical approach also includes postcolonial perspectives on immigration enforcement. This framework is incorporated with the goal of emphasizing a key aspect of removals in Canada not captured by viapolitical and Foucauldian lenses: namely that contemporary expulsions in the Canadian context are a product of settler-colonialism and a world order characterized by imperialism as well as colonialism.

\subsubsection{Viapolitics, Mobility in Carceral Practices and Contemporary Expulsion}

A viapolitical approach to researching deportation not only allows for the analytical centering of vehicles and routes of removal, it also broadens our spatial imagination of expulsion. As Casas-Cortes et al. note, focusing on transit paths and 'riding routes' enables an appreciation of the complexity of movement in migration (2015). It is easy to imagine that a deportation involves the efficient forced mobilization of a migrant from point 'a,' located in the deporting state, to point ' $b$,' at the migrant's deportation destination. However, visually reconstructing the itinerary of an individual's 
deportation passage challenges this simplistic spatial configuration and allows us to instead consider the indirectness of a removal involving multiple transit points and connecting flights. Recall Jama's itinerary: his deportation passage began in Edmonton and would take him to Calgary, Amsterdam and then Nairobi before he arrived at his final removal destination in Mogadishu (see Figure 2). ${ }^{5}$

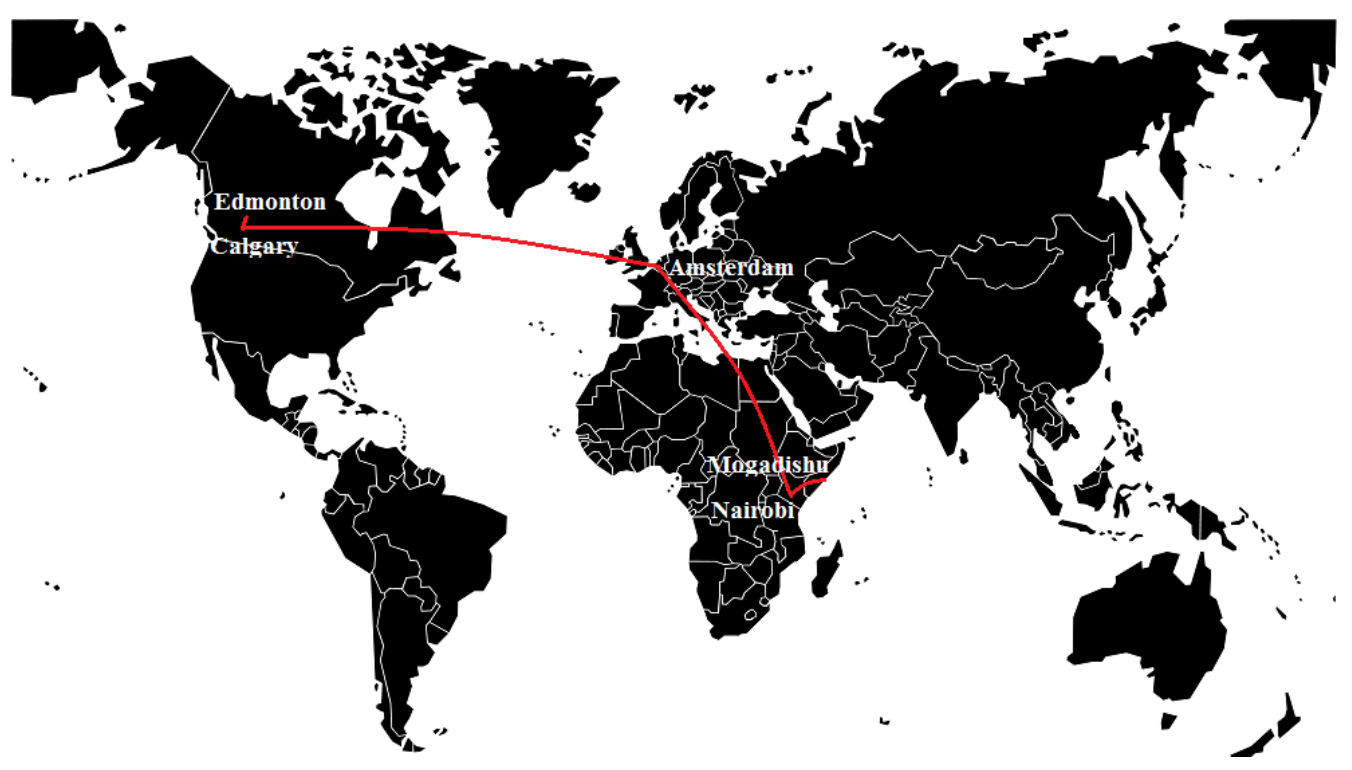

Figure 2 - Saeed Jama's Removal Passage (Zilio, 2013)

Furthermore, researching deportation through the vantage point of viapolitics necessitates empirical reflection on the logistics informing the organization of removals. We often think of deportation without considering the logistical and operational factors contingent to its realization. According to Neilson and Rossiter, logistics serve as key technologies of control that allow an 'informatized sovereign' to efficiently manage 'risks' associated to mobility using politically-charged 'logistical worlds' made up of software and infrastructure (2014 and 2010). Without the 'logistical world' enabling deportation in Canada, statist officials would be unable to keep track of those they deem

\footnotetext{
${ }^{5}$ Figure is a geographic approximation.
} 
undesirable and it would be impossible to coordinate with airlines and state officials from other countries to effectively organize a removal. Software and other components of the 'logistical world' of deportation are therefore fundamental for a range of processes and products forming part of the removal apparatus, such as the procurement of a third-party transportation provider and the maintenance of files containing training materials for recently-hired immigration enforcement officers.

A number of scholars within the sub-field of carceral geography have also pointed to the importance of considering the mobility and in-between-spaces inherent in carceral practices such as deportation. Gill challenges the commonly posited association between mobility and freedom and confinement and stasis by acknowledging the prevalence of forced movement in carceral environments, which he argues is often used punitively by officials to provoke discomfort through relocation and reduce the visibility of the imprisoned (2013). Michalon further notes that beyond the brick and mortar of the prison or the immigration detention centre, "confinement is also located in spaces of mobility" (2013). An observation supported by Moran et al. in their study of modern-day prisoner transportation in Russia, a case they use to discuss the "experience of transportation outside the prison," thus challenging "the binary distinction between inside and outside" (2013).

\subsubsection{Foucauldian Analytics and the Deportation Flight}

My viapolitical analysis of deportation flights in Canada also draws heavily on topological approaches to Foucauldian understandings of power. In developing this theoretical framework, Collier argues that "existing techniques and technologies of power [can be] re-deployed and recombined in diverse assemblies of biopolitical government" 
(2009), suggesting that specific power configurations can change over time, leading to new but similar practices, each with their own unique (re)combination of sovereign, disciplinary and governmental powers. When viewed through this lens, contemporary practices of immigration-related state-led forced migration can be linked to past forms of expulsion previously exercised on a local or imperial level. As Walters notes, antecedents to deportation include exile, banishment, prisoner transportation, population transfers, corporate expulsions, etc. (2010). What has distinguished deportation from these and other past forms of expulsion in Canada is its legitimation within the liberal-statist world order, its association to border control and its status as a merely 'administrative' procedure.

Sovereign power is understood by Dean as "a complex of powers unto itself" which includes "the powers of death, of punishment and of coercion" (2002). Dean adds that sovereignty also typically claims territoriality, an affinity to spectacle, a monopoly over the legitimate use of force, and can be understood as the power to decide on the state of exception (2002). In the case of modern deportations, the Canadian state is the authority empowered to legitimately decide on and carry out the physical expulsion or metaphorical death of the unwanted. While Foucault believed that the state's influence as an organizing power should be decentred (Brown, 2008), its role in shaping and executing deportation processes cannot be ignored.

Moreover, non-state agents and international actors also contribute to the creation of statist deportation policy and the operationalization of removals. For example, as per the Tokyo Convention of 1963, airline pilots are able to exercise a power akin to sovereignty in having the authority to physically arrest, restrain, and disembark a 
passenger if they are perceived as being threatening to the safety of the flight once the external doors of the aircraft have been closed (United Nations, 1963). Migrants have therefore been known to physically resist deportation once aboard the aircraft in order to have themselves and their CBSA escorts kicked off the deportation flight, thus delaying their removal from the country. Ellerman has also noted that unilateral migration control impedes on the interests of foreign states and that the enforcement of a state's deportation operations consequently requires the cooperation of international partners (2008). When executing a removal, the CBSA must therefore respect the sovereign requirements of the transit countries and destination state implicated in the deportation passage.

Furthermore, Gibney argues that deportation can be described as a type of forced migration, one legitimized by the normative underpinnings of a world order in which territorially-defined states are considered the norm (2013). The historic drawing of borders and normalization of this Westphalian system has resulted in a unique paradox: although humans have always migrated and exercised a fundamental freedom of movement, the statist world order assumes stasis and therefore binds mobile populations to nation-states despite the fact that state-members (citizens) often leave their country of nationality and go elsewhere. Border-crossing therefore poses a unique challenge to the sovereignty of nation-states seeking to assert control over populations within their jurisdictions, a challenge which individual states have sought to address through disciplinary policies of immigration enforcement. Gibney therefore notes that within the liberal-statist framework, 'deportation power' is seen as “correlative with the State's [sovereign] right to control the entry of non-citizens" within its borders (2013). 
The disciplinary influence of deportation and other immigration enforcement tactics has far reaching effects for migrants in Canada. 'Discipline' can be understood as the power to influence collective groups of individuals through surveillance and normalization. Collier suggests that this type of governmental power flows "through the capillaries of collective life" and operates through knowledge by "shaping the conditions of possibility for certain ways of thinking and acting" (2009). While deportation can be conceived as a spectacle in which sovereign authority exercises its use of discretionary force, it can also be understood as a technology of discipline.

In their study of temporary and unauthorized agricultural workers in Southern Ontario, Basok et al. note that deportation not only functions to remove inadmissible persons from Canadian territory, deportability also keeps precarious migrants "efficient and compliant" in relation to Canadian immigration laws, social expectations and employer demands since failing to abide by these disciplining pressures can result in migrants being reported to the CBSA and slated for removal (2014). Individuals wanting to establish themselves in Canada may also choose to leave the country to avoid falling into irregular status and becoming deportable. It can therefore be said that the threat of deportation contributes to the shaping of migrant's decision-making and social comportment.

The dynamics of a deportation flight also attest to the permeation of disciplinary power during the removal passage. During escorted removals, the presence of a state official trained in use of force techniques may deter a deportee from engaging in potentially risky behaviour such as drawing attention to themselves in an attempt to stop 
their deportation flight. The disciplinary presence of immigration authorities therefore shapes and normalizes migrant behaviour during removal operations.

The requirement in Canada that airlines pay carrier sanctions to the CBSA for transporting inadmissible persons into the country can also be described as disciplinary in nature. To avoid paying fees, airlines in Canada and elsewhere have adopted practices similar to those exercised by immigration enforcement officials: the CBSA even trains airline representatives to recognize fraudulent passports so that those with inadequate documentation will not be permitted onto a Canada-bound flight (CBSA, 2009a). In these instances, airline representatives exercise sovereign discretion during the embarkation process while simultaneously responding to the disciplining influence imposed by the CBSA through carrier sanctions.

The third Foucauldian form of power incorporated into this thesis is governmentality. According to Valverde, this type of governance extends beyond individuals and functions through regulatory techniques intended to manage risks affecting both the sovereign as well as the population (2007). Governmentality therefore seeks to regulate the 'conduct of conduct' and does so through the establishment of a range of governance systems that render the population or even a program legible. Aggregates of individuals can then be redirected by state and non-state authorities towards specific expectations, and reforms can be introduced to government programs to increase their efficiency or to enable state agents to more effectively meet governmental objectives.

While practices of deportation rely heavily on the power of sovereign authority and the policing logics of discipline, Walters argues that "in the course of the nineteenth 
century we can speak of a governmentalization of deportation" (2010). I provide two examples to demonstrate this point. Firstly, it can be argued that deportation has been used as a tactic by governments in an attempt to limit the risk of economic hardship on national-citizens. During the Great Depression, deportation in Canada was primarily used to remove foreign-born individuals in economically vulnerable positions since it was thought that eliminating the presence of these destitute migrants would allow welfare authorities to prioritize the well-being of Canadian citizens (Roberts, 1988). Walia (2013) and Golash-Boza (2015) suggest that similar logics are at play in present-day North America. The deportability of temporary foreign workers and other precarious migrant labourers renders them expendable. In times of economic hardship, they can be expelled from the country and replaced by Canadian citizens and permanent residents in need of work, even if many of the jobs precarious migrants occupy are commonly viewed as underpaid and undesirable.

Second, although a formative antecedent to deportation was the use of expulsion as a criminal sentence during the British Empire (Morgan and Rushton, 2013), Roberts describes how throughout the $20^{\text {th }}$ century, Canadian immigration authorities sought to use deportation's construction as an 'administrative' practice in order to circumvent the criminal justice system when dealing with foreign-born agitators, communists, anarchists and other 'radical' political dissidents (1988). Instead of criminally prosecuting the foreign-born for involvement in criminalized organizations, grounds of inadmissibility were expanded in the 1910 Immigration Act in order to facilitate the removal of those considered politically undesirable. These changes were strategic and deliberate: Canadian provisions to remove 'dangerous' persons were created based on legislation copied from 
the US, which was in turn developed through the work of a special Washington-based bureau responsible for dealing with anarchist elements present in the country (Roberts, 1988). Sovereign powers of deportation were therefore governmentally reformed in Canada in order to discipline and punish political dissidents using administrative functions.

Despite deportation's continued categorization as an administrative procedure, Dow argues that contemporary expulsions should be considered punishment 'in purpose and effect' since the removal process continues to use and adopt many of the same penal technologies available to police authorities, including handcuffs, use of force techniques and the use of prisons (2007). These similarities have led some scholars to argue that processes of 'illegalization' are increasingly reliant on the criminalization of migrants, leading to the rise of what has been termed 'crimmigration' (Walia, 2013; Stumpf, 2006; and García Hernández, 2015). This phenomena is especially visible in instances in which racialized migrants have been targeted by the police and then handed over to immigration authorities for deportation. In Canada, migrants are also commonly held indefinitely and without charge in provincial and federal prisons alongside formally criminalized populations.

Ashworth and Zedner nonetheless make an intriguing argument usable to highlight a key shortcoming within 'crimmigration' perspectives: they contend that the growth of quasi-criminal yet formally civil or administrative procedures has led to an issue of what can be considered 'under-criminalization' in a (very) limited sense (2010). The use of severe coercive measures in non-criminal instances (such as deportation) has resulted in individuals having limited access to procedural protections and other 
safeguards typically afforded to persons within criminal law (Ashworth and Zedner, 2010). For this reason, if deportation were in fact a criminal procedure, migrants would have more rights and protections in comparison to what they receive now under the current administrative framework. Ashworth and Zedner clarify that this state of affairs should not necessarily be remedied by formally criminalizing currently civil or administrative procedures. Instead, appropriate due process rights should be extended to protect persons without access to the safeguards of the criminal justice system (2012). In his research on the regulation of immigration in Canada, Velloso makes similar arguments calling for more safeguards and greater standards of proof in administrative immigration proceedings (2014). Regardless, state authorities in Canada and elsewhere continue to monitor and adapt the ways in which removals are carried out beyond the reach of criminal law using technologies characteristic of governmentality such as evaluation studies, pilot projects and departmental performance reports.

\subsubsection{The Rise of the Settler Colonial Canadian State and Deportation}

Finally, theorizing removal operations in Canada necessitates acknowledging the settler-colonial dynamic at play in the Canadian context, a distinct feature of the Canadian nation-state underlying all aspects of the polity, including practices of expulsion. As Haig-Brown notes, in "North America nations have been superimposed on Indigenous lands and peoples through colonization and domination" (2009). The lives of all people in Canada are consequently shaped by colonial processes that allow settlers, including migrants, to make themselves at home in a nation built on stolen indigenous landscapes. 
According to Coulthard, European actions towards Indigenous nations in North America can been rationalized through the logic of settler-accumulation (2008). For this reason he identifies colonialism as "a form of structured dispossession" motivated in the early Canadian context by the desire for land to accommodate sovereign-imperial European expansion (Coulthard, 2008). This expansion eventually led to the formation of the modern Canadian state. The colonial drawing of artificial nation-state boundaries and the continued enforcement of these delineations through contemporary bordering practices is therefore described by Walia as aspects of 'border imperialism' (2013). This colonial power configuration negatively affects the spatial distribution and mobility of both migrant and Indigenous communities, which must abide by settler-colonial legal frameworks that enforce the enclosure of the commons despite the historic regularity of human movement and migration. Jafri further comments that while migrants can be seen to benefit or be complicit in the ongoing colonial violence of the Canadian project, they are not necessarily privileged subjects within the nation-state (2012). The perceived 'otherness' or 'foreignness' of the migrant allows for their removal on deportation flights at the same time that indigenous communities are denied unrestricted mobility within their ancestral homelands.

What postcolonial theory can contribute to a study of Canadian deportation flights is the understanding that border enforcement practices such as air mode removals are a product of settler-colonialism. For this reason, it can be argued that the logics that allow for Canadian deportation flights to occur have emerged as a consequence of the imposition of European statism in lands where human movement has traditionally been normalized. Deportation and the nation-state itself can consequently be interpreted to be 
accidental and colonial fabrications allowing for the arbitrary forced removal of the territorially present undesirable. It is also important to acknowledge that practices allowing for these cotemporary removals are intrinsically linked to historical genocidal tactics aimed at removing Indigenous peoples to clear land for settlements.

In contestation of Canada's settler-colonial deportation regime, Indigenous scholar Lee Maracle has suggested that migrants threatened with removal should counter Canadian immigration laws with the Indigenous Host Laws which assert that "everybody eats, every woman has a right to a house and everyone has access to the wealth of the land" (in Walia, 2013). In the US, Indigenous activists have similarly demonstrated solidarity with migrant groups. In 2010, organizers native to Arizona occupied Border Patrol offices in Tucson in solidarity with migrants "indigenous to other parts of the Western Hemisphere" to issue a statement "demand[ing] a return to [the] traditional indigenous value of freedom of movement for all people" (in Smith, 2013).

Lawrence and Dua nonetheless contend that existing colonial tensions between Indigenous people and settlers of colour have led many Indigenous scholars and thinkers in Canada to remain silent on issues such as immigration and multiculturalism (2005). Others have also suggested that Indigenous peoples and migrants to Canada are at odds against each other when it comes to employment programs and other government services (Fife, 2016). In response to these critiques and in acknowledgment of migrant complicity in colonization, migrant justice groups in Canada such as the No One Is Illegal (NOII) network have strived to 'decolonize' their efforts and to engage in acts of indigenous solidarity to build relationships with local Indigenous groups (Fortier, 2013 and Walia, 2013). These efforts have led to several instances of cooperation: in British 
Columbia, Sewepemc land defenders have offered to host migrants fleeing deportation (Grewal in Walia, 2013). Anti-deportation campaigns in the Vancouver region have also resulted in Nisga'a elders meeting with migrants threatened with deportation to welcome them onto Indigenous lands (Grewal in Walia, 2013). This entanglement between migrant justice activism and indigenous decolonization work is an interesting feature of resistance to deportation in Canada and stands in contrast to migrant justice organizing in nonsettler colonial contexts. ${ }^{6}$

Scholars such as Mignolo (2006) and Kipfer (2011) have additionally pointed to the colonial dimensions of deportations globally. Deporting states are often nations from the Global North, while those that receive deportees are commonly countries located in the Global South. Furthermore, many deportation receiving nation-states are former European colonies, indicating that deported migrants can often be historically linked to the countries from which they have been expelled when a postcolonial perspective is applied. Canada, the US and other settler-dominated former colonies such as Australia are exceptions: while they are also sites of former (and ongoing) colonial violence, their distinct relationship to European imperialism affords citizens of these nation-states mobility-privileges not extended to nationals of other colonized countries.

\subsection{Researching Airborne Removals}

The scarcity of academic and public attention devoted to the Canadian state's removal operations can be attributed in part to the secretive conditions in which the work

\footnotetext{
${ }^{6}$ While the aforementioned example of anti-deportation resistance practiced by activists native to Arizona evidences the existence of a similar dynamic at play in parts of the US, more research is necessary to investigate the extent of this collaboration in that country. More research should also be done on migrant justice activism and indigenous decolonization movements in other settler-colonial states to determine whether instances of solidarity-building between these two movements is common in those contexts.
} 
of deportation is carried out. While individual high-profile deportations such as Jama's may lead to the occasional news story or radio documentary, immigration laws are more commonly enforced behind closed doors and away from public oversight. This secrecy and the relative small-scale of Canada's removal program work in tandem to obstruct extensive public consideration of contentious practices. Researching deportation and the vehicles used to carry out removals consequently necessitates the use of a critical mixedmethods research strategy, one involving multiple data-gathering techniques.

Deportations are complex operations requiring careful coordination between Canadian officials, foreign officials, airlines and security service providers amongst others. The process of designing, monitoring, restructuring and carrying out a removals program, along with the necessity of making logistical arrangements to carry out deportations, therefore results in an extensive electronic and paper trail traceable to government hard drives, filing cabinets and information systems. It is within this publically unavailable data, consisting of government email chains, powerpoints, internal evaluation studies, briefing materials and other similar documents, that one can trace the secretive logistical world of Canadian deportation. Access to information (ATI) requests provide powerful, albeit limited, tools to investigate state practices in such closed contexts.

Canada's Access to Information Act (ATIA) was established in 1985 with the goal of increasing government transparency and accountability by providing the public with a legal mechanism to request information from the government that would otherwise not be found in the public domain. A data gathering strategy commonly associated to 
journalism, the ATI process allows researchers to partially uncover documents detailing how government programs are designed and operationalized.

I began my research with seven completed ATI request release packages related to deportation in Canada that were provided to me by thesis supervisor, Professor Walters. After analyzing these disclosures, I submitted a number of ATI requests to the CBSA that were inspired by the content within the release packages. The majority of these were what Parsons describes as 'broad requests,' meaning that they were sent for exploratory reasons, to gather whatever information could be disclosed on the underexplored issue of Canadian deportation not covered by the seven initial ATI disclosures incorporated into the project (2015). These broad requests were then followed up by 'narrower requests' which honed in on specific documents mentioned in ATI disclosures and other publically available corporate documents (Parsons, 2015). Overall, 24 new ATI requests were filed over the course of this research project. Another 15 previously completed ATI requests related to deportation (and available on the Canadian government's Open Portal webpage) were also used to inform the background research process. Empirical evidence obtained through the ATI process was then selectively incorporated into the thesis depending on relevance as the various chapters began to take shape and direction. ${ }^{7}$ The majority of the ATI requests I made were sent to the CBSA. Requests were also sent to CIC and to Global Affairs Canada (GAC). It is from the resulting ATI disclosures that a significant portion of the empirical evidence in this thesis is sourced.

\footnotetext{
${ }^{7}$ All ATI disclosures incorporated into the finalized version of this thesis are listed in the works cited section.
} 
Canada's ATI process is not without its limitations. In fact, a number of organizations have critiqued the Canadian government for its continued used of an outdated ATI system (Cribb, 2015). To highlight a few common concerns, Cribb describes government transparency in Canada as being defined by an "unspoken code of silence" enforced through a "bureaucratic fortification" (2015). Walby and Larsen additionally note that in light of the ATIA, the Hawthorne effect has permeated government record keeping, meaning that state agencies have adapted their practices when handling sensitive information in full awareness that the documents they produce and work with may be requested through ATI (2011).

Monaghan adds that there are four major barriers to ATI in Canada (2015). First is the political control of information by ATI coordinators, offices of primary interest (OPI), government communication officers, and even senior officials who interfere in the ATI process for vague security reasons or to protect government departments from public scrutiny or embarrassment. I experienced this barrier first-hand when requesting information related to the CBSA's proposed escorted removals pilot program. The 30page disclosure that I received contained very little information about the project. In fact, only the first four pages of the disclosure were actually related to my request and the data within these pages was already largely available through public sources. The rest of the disclosure discussed 'efficiencies' introduced to the CBSA's removal function but did not contain any information specific to the proposed pilot. The disclosure package itself indicated that the information had been exempted for privacy reasons, to not "interfere with contractual or other negotiations with a third party," because the severed sections contained "advice or recommendations developed by or for a government institution or a 
minister of the crown" and because the material it covered contained "an account of consultations" involving government employees (CBSA, 2015c).

While these exemptions are all 'technically' permitted under the ATIA, I suspect that they may have also been made to limit public scrutiny towards the privatization of a controversial government practice. I assume this based on another ATI disclosure I analyzed during the research process, which contained an email chain in which CBSA officers discussed making media lines for use should anyone solicit information regarding privatization following the publication of a Rabble.ca news article critical of third-party involvement in removals (CBSA, 2012a). ${ }^{8}$ The news article had been flagged by the CBSA's media monitoring team, demonstrating the agency's efforts to contain and control messaging on the topic of privatization. I therefore believe that efforts were made to politically control the information released in response to my ATI request given political sensitivities related to privatizing sovereign governmental functions.

In another instance, I reached out to an ATI coordinator about delays I was experiencing while requesting security service provider contracts held by the CBSA and was told that there was a setback in releasing the information because the CBSA's ATI office disagreed with the recommendations of the OPI. ${ }^{9}$ The disclosure was late because the coordinator was going page by page and line by line "to try to have information released" (personal communication, August 19, 2015). A later email related to the same request indicated that the ATI office was advocating "for more information to be released" in light of continued disagreement with the OPI (personal communication, December 3, 2015).

\footnotetext{
${ }^{8}$ For the article, see Behrens, 2012.

${ }^{9}$ For the resulting disclosure, which was eventually released, see CBSA, 2015d.
} 
This experience also evidences Monaghan's second critique of Canada's ATI process, namely the significant time delays and fees that may result following the submission of a request for information. Although the ATIA allows government agencies a window of 30 days to respond to an ATI request, long extensions are commonplace and delays often progress past agency set deadlines. A number of the ATI requests I submitted over the course of this research project have yet to be disclosed and some of these submissions were made over a year before the time of writing. The topics of some of these unanswered requests hint at some political interference. One asked for documents related to any deaths or serious injuries sustained by migrants during the removal passage as well as documents related to escapes (CBSA, 2015e). Another requested information on the use of chartered aircraft during deportations (CBSA, 2015f). A third inquired about US Immigration and Customs Enforcement (ICE) involvement and collaboration in Canadian deportation operations (CBSA, 2015g). All three of these requests were therefore concerned with sensitive topics the CBSA might have been unwilling to disclose for political reasons. Time delays may therefore be argued to be occasional tactics of political interference in the ATI process. Other possible explanations include governmental inefficiency and overworked ATI coordinators and OPIs.

A third barrier to ATI in Canada is superficial and arbitrary document retrieval. According to Monaghan, ATI offices, and even the Office of the Information Commissioner of Canada (OIC) which oversees the application of the ATIA, are "underfunded, under-resourced and understaffed" (2015). These pressures often result in ATI coordinators selectively searching out and including documents in ATI disclosures, since they neither have the time nor the knowledge to locate files found in large 
government departments. Release packages therefore contain documents handpicked by government officers, rather than the full breadth of information that might otherwise be available. My experience requesting information on the escorted removals pilot project speaks to this limitation. Also telling is another instance in which I requested documents submitted by Canadian immigration authorities to the UK Independent Advisory Panel on Non Compliance Management (IAPNCM).

The IAPNCM was formed following the death of a migrant by the name of Jimmy Mubenga who perished during a deportation flight from the UK. In the period that followed it was determined that inappropriate use of force techniques employed by racist and under-trained third-party escorts had been responsible for the mortality. The IAPNCM was therefore created to develop a report outlining ways to make removals from the UK safer for deportees. The resulting publically available government document notes that Canadian immigration officials were consulted by the IAPNCM while it was gathering information about removal practices in other countries. The report also states that Canadian authorities submitted information to the advisory council, which is evidenced within the report through descriptions of Canadian use-of-force techniques (IAPNCM, 2014). However, when I contacted the CBSA to request the documents that had been submitted to the IAPNCM I was told that "no records were found that respond[ed] to [my] request" (CBSA, 2015h). Since a Canadian response to the IAPNCM's request for information is explicitly mentioned in the document of a foreign government, the CBSA recommended that I try submitting an ATI to GAC to see if perhaps this government department could release the documents I was seeking. Shortly thereafter, GAC responded that they had not found the documents I had requested (GAC, 
2015a). An ATI request sent to CIC also came back with the same response (CIC, 2015a). This experience shed further light on the challenges associated to conducting research on secretive and closed contexts using ATI: while the Canadian government was willing to share information on Canadian removal practices with representatives of a foreign government who were then free to publically distribute the content, it proved less willing (or able) to share this same information with a member of its own public.

The last barrier to ATI mentioned by Monaghan refers to the extensive redactions made in ATI disclosures and the limiting effect that these severances have on the quality of information released into the public domain (2015). As previously mentioned, government agencies have the discretion to withhold files or obscure information deemed exemptible by the ATIA. However, Monaghan asserts that a number of cases demonstrate that "governments apply exemptions to records more broadly than is necessary, particularly with sensitive files" (2015). Redactions may therefore hide useful information or confuse researchers and it is because of these barriers that ATI disclosures have been described by researchers such as Walby and Larsen as carefully-mediated texts that can only be counted on to provide a partial entry-gaze into government policies and programs (2011). My experiences seeking information on the escorted removals pilot project and on contracts with third-party service providers again speak to this fourth limitation.

One other major limitation I encountered while conducting research using ATI as my primary data gathering strategy relates to record keeping. A few of my requests were met with the response that the CBSA did not calculate the statistics I had requested. Evaluations of the removal function conducted by Canada's Auditor General have also 
commented on the CBSA's data quality. In 2008, the Auditor General rebuked the agency's failure to keep the statistics necessary to adequately manage and analyze the number of people in immigration detention and the length of these individual's incarceration. The CBSA also lacks exit controls, meaning that there is no way of knowing how many migrants subject to deportation have already left Canada without informing authorities, which may lead officials to overestimate the resources needed to carry out the removal program's mandate (Office of the Auditor General of Canada [OAG], 2008). Another major gap in record keeping relates to gender. When processing paperwork after a removal, officers are required to submit the migrant's "tombstone" data (CIC, 2010). This instruction is not only indicative of the grim nature of modern day expulsions, it also prevents a statistical breakdown of deportations by gender, whatever those genders may be. Although it is commonly understood that brown and black men are the most frequent targets of removal, there is little statistical information tracking the number of women, men and other genders who are removed from the country. It has also proven difficult to determine the number of minors channeled through the removal system in any given year.

According to the OIC's annual reports, CIC, GAC and the CBSA all consistently rank within the top ten government agencies in terms of most complaints received by the OIC on ATI requests (2014). While there were a number of ATI disclosures I would have liked to challenge through the OIC, no complaint mechanisms were pursued in the course of this research due to time and resource constraints. Despite the various limitations I encountered during my research, the information that I did receive provided an extensive amount of useful data regarding deportation flights in Canada. To fill in the gaps, I also 
incorporated news articles, government corporate documents, materials from migrant justice groups, airline documents, and international legal documents and guides into my data gathering strategy. Pulling information from multiple sources outside of the ATI process is a tactic in ATI research recommended by scholars such as Gonzalez (2012) and Walby and Larsen (2011) since using alternative data sources allows researchers to address the limitations of the ATI process.

The textual data collected through this critical mixed methods research strategy was then interpreted using a somewhat informal approach to critical discourse analysis (CDA). According to Fairclough, CDA is a useful technique when seeking to understand unequal power relations as they manifest through written and spoken language (2001). I therefore used CDA to evaluate the textual data found in the ATI disclosures and other documents reviewed over the course of this research project. This involved analysing the textual data for meaning, and then critically assessing the hidden meanings, or power dynamics, behind the chosen language using insights afforded by my chosen theoretical framework. The resulting observations were then synthesized into the chapters of this thesis.

\subsection{Organization}

The remaining chapters of this thesis present my major research findings and are organized around three general themes. The first chapter discusses technologies of expulsion predating the rise of civil aviation. To do so, it presents what can be considered a literature review of existing research on historical practices of removal to explore the theme of what came before the deportation flight. I used a viapolitical research approach when analyzing the literature reviewed and therefore focus on what others have said 
about the logistical organization of removals historically as well as the vehicles of expulsion used to carry out these past acts of coercive mobilization.

The third chapter of this thesis focuses on 'air deportation' in Canada, including its particularities, vulnerabilities and strategic value to modern deportation systems. I also provide a description of how removals are bureaucratically categorized and operationalized in the modern Canadian context. The final content chapter presents a description of Canada's growing 'migration control industry' and focuses on the implications of outsourcing aspects of removal to third-party service providers such as airlines, 'fixers,' and private escorts. I conclude this thesis with a short section wrapping up the main arguments and findings of my research. This concluding chapter also identifies areas of research for future investigation. 


\section{Chapter 2: Antecedents to Contemporary Removals in Canada: A Viapolitical Analysis of Selected Literature on Past Expulsions}

\subsection{Introduction}

Airplanes have emerged as a means of expedited transportation not only for those wishing to cross the physical border into Canada, but also as a technology upon which immigration authorities rely to forcibly remove Canada's deportspora from the Canadian landscape to their deportation destinations around the world. ${ }^{10}$ Without the advent of aviation, removals could not occur as quickly, as commonly or as globally as they do today, leaving authorities to instead rely on slower, less sanitized and more lethal coercive transportation technologies to affect expulsions.

Forced removals similar to deportation have nonetheless been a significant aspect of the Canadian settler-colonial experience for some individuals dating back to before the advent of the aircraft, the formal legalization of deportation as a state practice or even the creation of the Canadian nation-state. This next chapter will therefore selectively describe historical instances of expulsion that have taken place on the modern Canadian landscape while also discussing what I have been able to glimpse of the transportation systems (or lack thereof) upon which they relied. The goal is to present an account of how the mechanics of removal have transformed historically and to provide a viapolitical analysis of available literature on deportation in Canada to highlight what these existing works contribute to an understanding of the removal journey as it existed in the past.

\footnotetext{
10 The term 'deportspora' was coined in Nyers, 2010.
} 
I pursue this goal acknowledging that descriptions of coercive systems of mobility are commonly a background detail in much of the literature on past expulsions in Canada. Through my review, I have nonetheless been able to create an informative if imperfect picture of the how past removal systems have operated, allowing for a deeper appreciation of both the distinctness and historical relatedness of deportation in the present to these antecedents. In this chapter, I also hope to demonstrate how the work of expulsion has continuously adapted with the emergence of new transportation technologies and different types of migration flows. I likewise provide an account of how constructions of deportability have shifted from the colonial period when expulsions took place on foot and on sail-based maritime vessels up until shortly before the integration of aviation as a technology critical to the functioning of the Canadian deportation apparatus, when removals relied on railway and steamship transportation.

\subsection{Removals before the Emergence of the Canadian State}

Due to its settler-colonial origins, Canada's history of expulsion is intrinsically tied to and influenced by its imperial predecessors. For this reason, some of the first removals that took place on now-Canadian territory can be described as part of a larger imperial story of sovereign British and French military involvement, colonization and 'desirable' settler-expansion in North America. Correspondingly, some of the first removal vehicles used in Canada were maritime vessels commandeered by European forces. However, there is also evidence of early expulsions taking place without the coordinated use of vehicles and other removals involving contracted merchant vessels. The attempted removal of the Mi'kmaq, the expulsion of the Acadians, the return of Irish convicts transported to Newfoundland and the removal of the Trelawney Maroons 
provide examples of how expulsions occurred before the territorialisation of the Canadian-state while also demonstrating the diverse sovereign tactics used to expel settler or European populations in comparison to Indigenous and other racialized peoples. These four distinct examples also demonstrate how contemporary removal practices are part of an extensive history of expulsions in Canada traceable to the colonial period.

Kanstroom notes that colonial practices of removing indigenous peoples from their ancestral lands is an important antecedent to deportation in settler-colonial North America (2007). Many early expulsions that took place without the coordinated use of vehicles commonly involved indigenous populations, demonstrating the different tactics used to remove colonized groups in comparison to non-indigenous settlers. American examples such as the Cherokee Trail of Tears and the removal of the Choctaw are well known, and characterized by coordinated governmental efforts on the part of the US army to forcibly expel indigenous peoples from their traditional landscapes. Less well known are somewhat comparable removals in the early colonial Canadian context, some of which were carried out using bounties and other threats of extermination. One such instance was a British effort to provoke the forced emigration of the Mi'kmaq located in modern-day New Brunswick and surrounding areas in the mid-1700s.

At the time, British and French troops were fighting for imperial control over lands in North America and both forces had created alliances with different Indigenous groups. The Mi'kmaq were allied with the French while the Iroquois sided with the British. According to Paul, these two indigenous groups fought for territorial dominance over hunting grounds strategically located amidst the networks of the fur trade (2000). They both also maintained a traditional relationship to the land under contestation (Paul, 
2000). Though France had given up claims to lands in Acadia by the early 1700s, the Mi'kmaq continued fighting in the region arguing that they had not agreed to this transfer of legal sovereignty to the British. The attempted expulsion occurred as British forces gained ground and initiated the settlement of ancestral Mi'kmaq lands previously controlled on an imperial level by the French.

In 1749, Edward Cornwallis, the governor of colonial British Nova Scotia (which at the time encompassed Acadia which is located in modern-day New Brunswick) formally declared war against the Mi'kmaq while proclaiming that "a reward of ten Guineas [would be given] for every Indian Micmac taken or killed, to be paid upon producing such Savage taken or his scalp" (Paul, 2000) $\cdot{ }^{11}$ Plank argues that the aim of this genocidal tactic "was to eliminate the Micmac population on the peninsula of Nova Scotia, by death or forced emigration" (1996). British forces therefore attempted to disciplinarily expel the Mi'kmaq by threatening their extermination using sovereign imperial force. While some surely vacated regions heavily controlled by British troops and settlers, Mi'kmaq military action against the British continued, shaping the contours of the subsequent expulsion of the Acadians during the mid to late 1700s.

The Acadians had claimed neutrality during the various conflicts between the British, French and their various indigenous allies. However, their cultural ties to France as a Catholic and French-speaking people, and their affective ties to the Mi'kmaq with whom they had intermarried, marked them as undesirable once British forces had secured military control over their settlements. British colonial authorities claimed that the Acadians were "popish recusants" and "had no returns of loyalty to the Crown, or respect

\footnotetext{
11 'Micmac' is a variation of 'Mi'kmaq,' which is the spelling most commonly used by Indigenous groups.
} 
to His Majesty's government in the province" (Akins, 1869). The settlers were also accused of actively assisting the Mi'kmaq and the French at the battle of Fort Beauséjour, and inadequately cultivating the territory in their possession (Akins, 1869). The British therefore concluded that since the Acadians had been "idle on their lands," they were "an obstruction to the King's intentions in the settlement" and their removal was subsequently organized (Akins, 1869). This rationale for expulsion not only speaks to powers of imperial sovereignty, it also has religious overtones while simultaneously hinting at some of the economic and social control logics at play in official explanations of the removal. Had the Acadians laboured on their lands in way more recognizable to British notions of propertied development, it is possible that the rationale for the removal would have been phrased differently.

Unlike the Mi'kmaq, Acadians in mainland Nova Scotia and surrounding islands were violently rounded up and displaced by military troops in a display of sovereign imperial force. Many of their settlements were also destroyed by fire to discourage the Acadians from returning (Lockerby, 1998). Lockerby further notes that maritime vessels, some contracted, others operated by the British Navy, were then used to forcibly transport the Acadians to locations in North America and Europe (1998). This was done through somewhat coordinated British removal operations carried out using existing maritime navigation routes - an example of forced movement that has been mapped out 


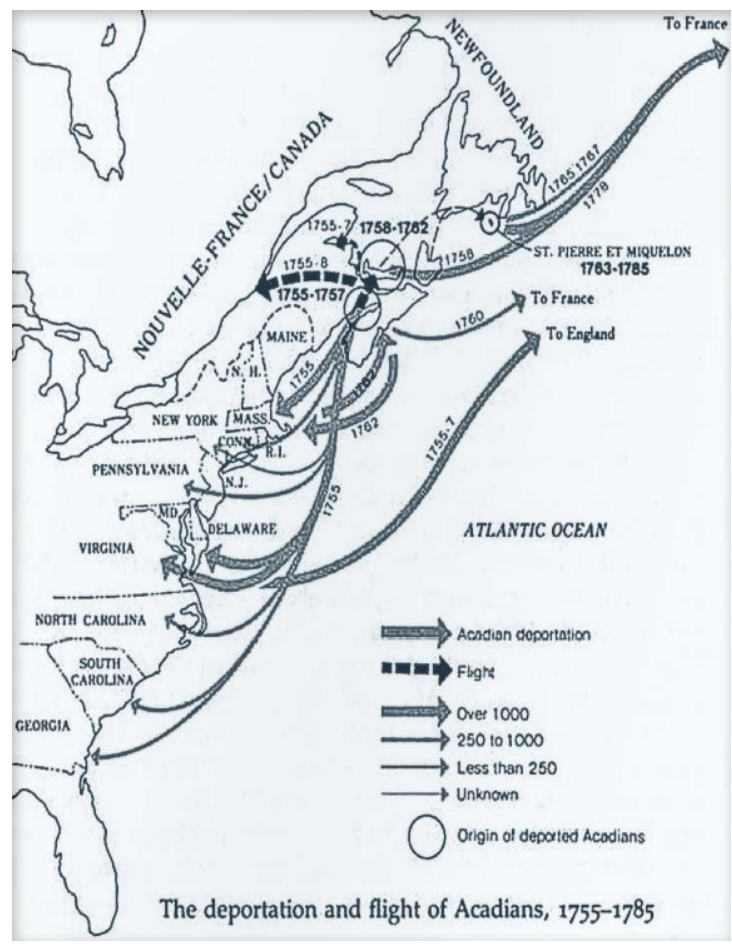

Figure 3 - Griffith's mapping of the Expulsion of the Acadians (1992) by Griffiths in their history of the Acadian peoples (1992) (see Figure 3). Griffiths also argues that some of the Acadians fled their homes upon hearing the news of what had happened in other settlements (1992), demonstrating the disciplinary effects of the threat of coercive expulsion. Notably, many of the expelled Acadians were rejected by the settlers of the areas to which they arrived and were therefore forced to continue their removal journey in search of other

destinations where they would be permitted to land.

According to Marsh, the Acadian expulsion resulted in a 53\% mortality rate, with a large number of the removed dying of starvation or illness aboard the over-crowded and at times decrepit ship vessels upon which they were transported (2013). Many of these vessels were older second-hand cargo ships that had been retrofitted specifically for the expulsion, and some of these vessels sank during the journey, resulting in significant loss of life (Landry, 1999). Lockerby additionally notes there is some evidence suggesting that colonial officials were aware of the unseaworthiness of a few of the ships used for the expulsion (1998), indicating that authorities knew that some of the removal journeys would likely result in shipwreck and death. The holds in which the Acadians were kept were also too small for many of the expelled to stand in and the space was too crowded for individuals to lie down. Landry further contends that the removed Acadians were not 
provided with sanitation facilities and that much of the food they were given was subpar, contributing to the high mortality rate during the removals, some of which lasted up to three months (1999).

Interestingly, a few Acadian families were able to evade sovereign British efforts to capture and remove them by turning to their Mi'kmaq allies, who hid displaced Acadians within their territories (Paul, 2000). This assertion of Mi'kmaq sovereignty and compassion towards the Acadians was almost immediately contested by the British through another scalping proclamation. In 1756, Cornwallis' successor Charles Lawrence once again proclaimed that a bounty would be given for the death or capture of any Mi'kmaq person (Paul, 2000). The continued use of this genocidal tactic of expulsion evidences enduring efforts by the British to provoke the forced emigration of the Mi'kmaq in order to accumulate land for desirable settler-colonial expansion.

Modern day Canadian deportations can also be linked back to the British criminal justice system. During the early years of British imperialism in North America penal practices of banishment, exile and prisoner transportation were used to expel criminalized British subjects to North American colonies. ${ }^{12}$ These forms of expulsion have been described by Walters as predecessors to modern deportation (2010), leading scholars such as Bleichmar to assert that deportation today should legally be considered a form of punishment instead of an administrative procedure (2000).

Although the punishment of banishment was reserved primarily for 'vagabonds' and those found to be political dissidents or religious outcasts, any subject sentenced to the death penalty (for crimes ranging from petty theft to murder) could instead appeal to

\footnotetext{
${ }^{12}$ These practices of expulsion were codified in the Transportation Act of 1718.
} 
the crown for mercy and in exchange be granted a pardon through expulsion to the Crown's conquered lands overseas (Morgan and Rushton, 2013). In other cases, individuals would petition for the punishment of transportation before their sentencing in fear of potentially incurring a harsher penalty should the sentencing proceed (Ekirch, 1985). The sovereign practice of prisoner transportation therefore became a key component of the criminal justice system in the British Isles and its threat was used by officials to discipline individuals into abiding by the law.

In the middle of these early removal operations was the sail-powered shipping industry. According to Ekirch, individuals subjected to prisoner transportation in England were typically removed aboard ships specifically contracted by the Crown to transport convicts to the Americas where they would be sold into temporary indentured servitude (1985). Bannister provides evidence of a similar system being used in Ireland, although the intermixing or disguising of convicts with Irish labourers was also common (1998). In Scotland, the prisoner transportation system was more decentralized. Individuals receiving the sentence or pardon of transportation had to finance their own passage or else face either execution or indefinite imprisonment within the jail cells of Scottish tollbooths (Ekirch 1998). The poor would therefore often sell their labour to secure passage by signing indentured servitudes with ship captains who were willing to transport them (Ekirch, 1998). Due to the hazardous conditions aboard removal ships, many individuals subjected to prisoner transportation from the British Isles died during the passage to British North America.

Of those who arrived, some were occasionally detained and slated for expulsion once again as it was not uncommon for prisoner ships to arrive without the advanced 
notice or permission of local authorities. According to Martin, after the American War of Independence, both the newly established US and British colonies and settlements that would eventually form Canada, uniformly began resisting the continued arrival of convicts from the British Isles (1975). The colonial Governor of Newfoundland would set an example of how such situations might be handled by colonial authorities in 1789 when he initiated the mass forced return of a group of Irish convicts who had been thrown overboard by their ship captain near the small fishing community of Bay Bulls (Martin, 1975).

The Duke of Leinster had initially set sail from Dublin carrying over 100 male and female convicts in the early summer months of 1789 . Bannister notes that after a month at sea, supplies aboard the ship began to run out and a fever broke out amongst the prisoners (1998). The captain, an Englishman by the name of Richard Harrison who had been contracted by the Lord Mayor of Dublin to transport the convicts, subsequently decided to rid himself of his human cargo. As he abandoned the convicts, Harrison told them to tell the authorities that they had sailed on a ship by the name of Charming Nancy in order to protect himself from possible prosecution for defaulting on his contract, which had likely required him to transport the prisoners to Botany Bay in New South Wales, modern-day Australia (Bannister, 1998).

In Bay Bulls, the convicts were accused of committing arson and of spreading disease. Authorities therefore decided to take action after they began arriving in St. John's (Bannister, 1998). Though many of the women and a few of the men are believed to have either integrated into the surrounding communities or died shortly after arriving in Newfoundland, the majority of the convicts were subsequently rounded up and 
detained (Martin, 1975). After enough money was raised by the local government and merchants in the area, the Elizabeth and Clare was contracted to set sail towards Spithead with 80 of the convicts onboard (Marin, 1975). The convicts were then sent to Spithead instead of Dublin as there were a number of legal complications surrounding their forced return that had to be cleared with the British before the convicts could be returned to Ireland (Martin, 1975).

By law, if the convicts returned to Ireland before their sentence of transportation had been completed, which typically required their banishment for a period of 7 years, they could be subjected to the death penalty for failing to meet the conditions of their initial pardon (Morgan and Rushton, 2013). Authorities from Newfoundland therefore set sail on a ship travelling alongside the Elizabeth and Clare in order to ensure the convicts safe return and while doing so initiated a legal process in both Ireland and amongst British imperial authorities that would set an example for how North American jurisdictions might legally deal with unwanted convicts who arrived on their shores (Martin, 1975). Although convicts had been returned to the British Isles before on an adhoc basis, the coordinated return of the Irish convicts from Newfoundland in 1789 therefore contributed to the establishment of a governmental precedent allowing for the return of undesired arrivals from jurisdictions that would eventually form Canada. Unable to sail all the way to Dublin due to leakages on the Elizabeth and Clare, the convicts were transferred onto a coasting vessel at Portsmouth (Martin, 1975). They were then returned to Dublin after the legal complications had been sorted. Some of the convicts were eventually transported to New South Wales. 
Another form of expulsion that existed before the territorialisation of the Canadian state that can be linked to deportation practices in the contemporary context involves the removal of enslaved and free black populations. This relationship has been noted by Kanstroom, who also considers the transportation of fugitive and freed slaves in North America to be predecessor to deportation (2007). The expulsion of the Trelawney Maroons as described by Lockett provides a Canadian example of these early removal practices (1999).

The Trelawny Maroons were a community of escaped slaves in Jamaica who successfully acquired their freedom following a series of armed conflicts with the British. During one of these hostilities in the late 1700s, the Governor of Jamaica made a deal with the Maroons stating that if they surrendered immediately they would be left alone and allowed to remain on their lands. As soon as the Maroons put down their weapons, they were corralled and placed on a ship. Since they were considered a security threat, it was decided that removal was the best course of action and the Jamaican House of Assembly subsequently created a new statute legalizing the relocation of the Maroons. The law also stated that the Maroons would face the death penalty if they returned, evidencing once again the use of policing logics in sovereign expulsions during the age of empire. The group was then relocated to Nova Scotia where they lived for nine years before being relocated once more by British authorities to Sierra Leone in 1800. This final relocation was carried out using the HMS Asia, a 64 gun-ship belonging to the Royal Navy (Lockett, 1999). Although the Maroons were somewhat willingly taken to Sierre Leone as part of the 'Back to Africa' movement, foreshadowing the assisted voluntary returns of today, many would continue to resist their original expulsion from Jamaica by 
relentlessly petitioning imperial authorities to permit their return to their true homeland in the Caribbean. These efforts would eventually prove successful for some of the Maroons: in 1829, a number of them were permitted to return (Kofahl, 2014).

Similar to the Acadians, British colonial authorities arranged for the Maroon's relocation from their 'Canadian' settlements. However, this removal is different from the expulsions of the Mi'kmaq and the Acadians while baring some similarities to the expulsion of the Irish convicts because it evidences the increased normalization of logics of 'repatriation' and 'return.' While the Mi'kmaq were forcibly displaced on foot to locations beyond the reach of violent imperial conquest, and the Acadians were forcibly removed to essentially anywhere they could be relocated, the expulsion of the Maroons and the Irish demonstrates an attempt to repatriate a population to their perceived land of origin, namely Sub-Saharan Africa in the case of the Trelawney Maroons and Dublin in the case of the Irish convicts. The Acadian, Irish and Trelawney Maroon examples also demonstrate the use of contracted and military maritime vessels to carry out the actual forced transportation of undesirable populations while evidencing the Atlantic orientation and imperial dimensions of early expulsions in Canada.

According to Roberts, ad-hoc removals from now Canadian territory would continue until a few decades after the formation of the Canadian state (1988). Removal practices would subsequently become more systemized and governmentalized as nationbuilding became a priority. New vessels of removal would also emerge as technological innovation led to the invention of railway and steamship transportation systems. 


\subsection{Rail and Steamship-based Deportation post-Confederation}

The ability to enact what we now understand to be 'deportation power' was first granted to Canadian officials in 1867. After Confederation, the technology of expulsion was reconfigured to primarily fall under the jurisdiction and sovereignty of the Canadian nation-state as opposed to imperial authorities. At the time, immigration policy was highly influenced by the colonial era Quarantine Acts which aimed to limit the entry of sick migrants into Canada (Molinaro, 2011). The earliest Immigration Acts (passed in 1869 and 1872) also allowed officials to deny entry to the foreign-born based primarily on the grounds of morality, criminality, health and poverty (Molinaro, 2011). Individuals deemed to be undesirable were either denied entry into the Dominion of Canada and held in Atlantic ports or quarantine stations prior to being informally returned to Europe via the shipping companies that had transported them (Molinaro, 2011), or if they were determined to be 'public charges' within two years of arriving they could likewise be extra legally repatriated at the expense of their corresponding transportation company (Roberts, 1988). In these instances, municipalities (which handled the provision of welfare) would work with train companies such as the Canadian Pacific Railway (CPR) to transport the foreign-born to sea ports where they would be repatriated to "whence they came" (Roberts, 1988). Migrants to Canada from the US could be returned through land border ports of entry.

Robert's partial account of the deportation of Johan Altmeir provides an example of the removal passage experienced by an individual expelled in early days of the Canadian state. Originally for Austro-Hungary, Altmeir had been working for the CPR when he sustained a serious work place injury. Although he survived the accident, 
Atlmeir was unable to continue his work and was therefore ordered deported by immigration officials. He was first transported by the CPR from Winnipeg to Quebec. There he was taken aboard an Intercolonial train to Halifax where he was transferred onto a steamship run by the Allan Shipping Line to undertake the Atlantic passage (Roberts, 1988). This expulsion occurred before Canada had legalized deportation practices.

Powers of removal were formalized in the Immigration Act of 1906 and expanded in the Immigration Act of 1910. At this point, officials were authorized to remove anyone from Canada who was deemed to be "feeble-minded," "idiotic," "epileptic," "insane," "deaf," "dumb," "blind," "destitute," "vagrant," "criminal," anyone who had an infectious disease and anyone who became a public charge (Molinaro, 2011). Roberts notes that the Immigration Act of 1910 was also the first piece of Canadian legislation to allow for the removal of individuals on racial and political grounds. Furthermore, she comments that in expanding deportation legislation, Canadian authorities were seeking to legally formalize existing practices that had been previously carried out without legislative authority (1988).

A significant effect of these changes to deportation policy was that they allowed for the systemic disciplining and removal of foreign-born "agitators," "anarchists," "communists" and other types of political dissidents or activists from Canada in the first few decades of the $20^{\text {th }}$ century. For example, according to Roberts, in 1934 Tomo Cacic, a Yugoslavian who had been living in Toronto, was deported for his involvement in organizations such as the Workers Unity League (WUL) and his association with communist Tim Buck. After being detained at the WUL office, Cacic was taken to the Kingston Penitentiary where his deportation hearing was held (1988). Molinaro further 
documents that after his appeal process was exhausted, Cacic was picked up by two escorts, placed in a vehicle and taken to a train station some 50 kilometres away in Brockville, Ontario (2010). From there he was transported by rail to a remote location in Quebec and then transferred onto a train to Halifax. The Montcalm steamship departed Halifax enroute to Liverpool with Cacic onboard shortly thereafter. During the North Atlantic crossing, Cacic and another deportee onboard the Montcalm were watched over by guards and kept separate from other passengers. Then upon reaching Europe, Cacic was transferred between English and Dutch ports while his passage into the interior of Europe was arranged. During this time he managed to get into contact with British labour activists who helped him escape from Belgium where he was set to take a train to Yugoslavia (Molinaro, 2010).

As the removals of Altmeir and Cacic demonstrate, many of the first deportations carried out by state-officials were to destinations located in Europe. This geography of deportation reflected the places of origin of the first few waves of settlers who arrived to Canada during a period of highly-racialized and selective nation-building postConfederation. Deportations from the west-coast were nonetheless also common and became more prominent as nativist sentiments grew against members of the East and South Asian Diasporas situated in Canada.

The Continuous Passage Act of 1908 is a strong example of how legislation can be used to prevent and discourage 'undesirable' migrants from entering Canada based on the contingencies of naval transportation. Under this legislation, individuals who arrived on Canadian shores could be denied entry if the vessel on which they secured passage had stopped in other countries on the way to Canada, comparable to Safe Third Country 
agreements in affect around the world today. Since individuals wishing to migrate to Canada from East and South Asia had to travel aboard steamships that required several transit stops, the Continuous Passage Act had the effect of denying these racialized individuals entry into the country. The marginalizing outcomes of this legal arrangement were deliberate: Canada's predominantly white population at the time wished to limit the entry of non-white individuals into the country in order to allow Canada to establish itself as a white nation. While the main objective of exclusionary immigration rules was to discourage racialized migrants from coming to Canada, these policies also had a significant effect on removals. Individuals who arrived in contravention of the Continuous Passage Act or did not meet the requirements of similarly restrictive pieces of legislation such as the Chinese Immigration Act could be denied entry and/or removed from Canadian territory.

The infamous Komagata Maru incident of 1914 evidences these exclusionary practices of forced return at play. Upon arriving in Vancouver, only 24 of the steamship's 376 passengers were admitted into Canada and the ship was therefore prohibited from docking at the Vancouver harbour. After two months of legal contestation, the Komagata Maru was escorted out of Canadian waters by a warship with the remaining passengers onboard being forced to return to India (Goutor, 2007). While many individuals aboard the Komagata Maru steamship were never technically deported from Canadian soil since they were denied the ability to disembark from their passage, their experiences can nonetheless be understood as forced return as many had wished to establish themselves in Canada but had nonetheless been unwillingly removed back to their country of origin. 
The removal of Japanese Canadians during and after World War II provides a second example of racialized expulsion taking place in the Canadian nation-state before the emergence of air deportation. In 1942, Prime Minister Mackenzie King issued a number of orders-in-council allowing for the removal of those with Japanese ancestry from their homes in areas designated as 'protected' to camps located primarily in the interior of B.C. and across the prairies, with some being removed all the way to Quebec. In doing so, Mackenzie-King enacted sovereign powers of expulsion in order to assert a disciplining effect over a population considered suspect by the general public. According to Oikawa, around 22, 000 individuals were affected, with most being either born in Canada or having lived in the nation-state for 25-40 years (1999). In her research, Oikawa also describes aspects of the removal passage, which she calls the 'in-between spaces' of the expulsion, as experienced by a woman whose family ended up in Toronto after being forcibly relocated three different times. The first of these expulsions was from Vancouver to an incarceration site in Tashme, BC. The journey began after the family was violently removed from their home. They were then placed on a train and transported to Hope, BC, after which they were taken the remaining 14 miles to Tashme on a truck. In her interview with Oikawa, the woman recounts that travelling by truck "was a very primitive way of getting up there" (1999).

Oikawa's research also includes an interview with a woman by the name of Margaret who was child during WWII. During the removals, Margaret and her family were expelled from Vancouver to a sugar beet labour camp in Manitoba. The removal from Vancouver to Winnipeg was affected aboard a train over a period of four or five days. In her interview with Oikawa, Margaret recounted that the trip was "cramped," "hot 
and uncomfortable." Her and her family were unable to lie down for the duration of the trip and had to travel sitting on cane seats (1999). Another Japanese Canadian woman affected by the expulsion describes that the experience was "terrible and unbelievable" and that she was "kept $[\ldots]$ in the stalls were they put the cattle and the horses" in Hastings Park while she awaited a 'special train' set to take her to where she was being sent off (Marsh, 2012).

As WWII drew to an end, many interned Japanese Canadians, most of which were located in BC, were given the 'option' to be repatriated to war-torn Japan or to be relocated once again to an undisclosed location east of the Rocky Mountains at an undisclosed time with guaranteed employment lasting only for a few weeks. Sunahara describes how this option was in actuality somewhat of a false choice, similar to assisted voluntary return schemes in the present, since those who 'voluntarily left' were promised employment until their removal, "free passage, funds equivalent to the value of their capital in Canada" or free passage and \$200 per adult and \$50 per child "to sustain them until established in Japan" (1981). In comparison, those who remained were threatened to be categorized as "uncooperative" and were to be denied sufficient relief benefits from the government. Officials could also not guarantee that the relocation would be permanent as only one province, Saskatchewan, had disclosed a willingness to resettle the marginalized population (Sunahara, 1981).

When the war ended quicker than anticipated, some Canadian officials strived to make the signatures of those who had expressed a desire to be relocated binding (Sunahara, 1981). 4,319 individuals were subsequently removed from Canada. Around half were older Japanese-Canadians, many of whom spoke little English and were 
discouraged by their experience in the country, with the other half primarily consisting of adult offspring leaving to accompany their aging relatives and their dependents (e.g. spouses and under-aged children) (Sunahara, 2011). All who were unable to retract their repatriation requests on time were also denaturalized and removed, including many who spent their final days in Canada fighting the deportation order (Timmons, 2011). According to Timmons, many of the young deportees were especially opposed to their removal, as they were being expelled as dependents despite wishing to remain in Canada and retain their citizenship (2011).

Timmons describes how prior to the removal, and despite their status as voluntary repatriates, the deportees were detained without visitation rights at the Vancouver Harbour Immigration building under the supervision of the RCMP (2011). The first vessel, a US Navy ship by the name of S.S. Marine Angel, left Vancouver on the 15-day trans-pacific journey to the American-run Uraga Repatriation Centre in Tokyo Bay on 31 May 1946. The S.S General Meigs would take off Japan-bound from Vancouver on June 16 and then again on August 2. The final vessel used for the expulsion, the S.S. Marine Falcon would leave Vancouver on October 2 and on December 24 when the final removal passage to Tokyo Bay was realized. Many of the deported arrived sick and wishing to return to Canada (Timmons, 2011).

\subsection{Conclusion}

This chapter has focused on portraying how expulsions have been structured and executed in landscapes now recognized as Canadian prior to the emergence of air deportation. To do so, I have relied primarily on the work of historians and other researchers who have written about past events that form part of Canada's history of 
expulsion. The first section provided an account of expulsions prior to the territorialisation of the Canadian-state using examples such as the extermination order against the Mi'kmaq in the mid-1700s, the expulsion of the Acadians, the return of Irish convicts from Newfoundland and the 'repatriation' of the Trelawney Maroons. These four examples demonstrate how expulsions were carried out in the British imperial/colonial context using sail-based maritime technology.

The second section focused on the period following Confederation in 1867. I discussed early antecedents to the current legal and bureaucratic mechanisms of inadmissibility while providing a description of how individual removals were carried out using railway and steamship technologies before the normalization of air deportation. The removals of Altmeir and Cacic also evidence the ways in which acts of expulsion have been historically used by sovereign authorities to discipline the unemployed and political dissidents. The Komagata Maru incident and the forced relocation of Japanese Canadians during WWII also provide examples of racialized exclusion taking place with the use of past transportation technologies.

My intention with this chapter has additionally been to viapolitically describe how past expulsion practices were notable for their lengthy duration and their highly-visible association to marginalization, sickness and death. The next chapter will shift the discussion to this thesis' primary focus on air deportation, and how it has fundamentally rearranged the way the work of expulsion is carried out in Canada. I will argue that the differences between air deportation and the past removal processes described in this chapter function to 'sanitize' the contemporary removal system. While still violent, the work of deportation as it exists today is generally more humane when compared to 
historical expulsions and these differences in logistical configuration function to somewhat legitimize modern-day removals amongst the general public despite their direct relation to strikingly violent antecedents. I also note that many of the systems of categorization and partnerships with transportation companies that existed in the past have been reconfigured into new yet similar arrangements in the present. 


\section{Chapter 3: Contemporary Removals in the Canadian Context and the Normalization of Air Deportation}

\subsection{Introduction}

The rise of civil aviation as a global system of transportation has been emblematic of a distinctive human mastery over distance and space. We commonly associate flight to freedom, hyper- mobility, and world-wide interconnectivity, with the aircraft representing humanity's capacity to surpass the limitations of the terrestrial, thus redefining how people travel and acquire global experiences in the contemporary context. However, this likening of flight to freedom is disrupted when we viapolitically consider the role of the aircraft in violent and politically-charged contexts such as the deportation passage. Within contemporary removal systems, 'air deportation' has emerged as a key technology of immigration enforcement, one that has fundamentally changed the way the work of deportation is carried out in states with well-established removal systems. Not only do air carriers transport vacationers, expatriates, diplomatic staff and business travellers to their destinations around the world, civil aviation technology is also used to quickly, cleanly, and forcibly expel illegalized migrants from places in which they have been deemed inadmissible. For this reason, the aircraft can be described as a key weapon and critical component of the infrastructure of removal with which state officials enforce their control over both territorial sovereignty and undesirable populations.

In the Canadian context, the predominance of air deportation takes on added significance as a consequence of the landscape's geographic attributes. As a wide-spread Northern American country surrounded by three oceans and a single lengthy land border with the US, removals from Canada to non-US destinations commonly require the use of an aircraft. Internal deportation-related air travel also becomes necessary within such a 
regionalized territory because deportees located in the far reaches of the country must commonly transit through hub airports to reach connecting flights and to travel between different CBSA enforcement regions.

The removal passage itself can take on a variety of forms and can be transited using different types of vehicles of removal. In many instances, migrants are coerced into 'voluntarily' complying with their removal orders. While this modality of expulsion affords greater agency, it is important to question how freely migrants actually leave the country when asked to comply given the underlying threat of detention and forced removal should they refuse. In her review of Assisted Voluntary Return schemes in the European Union (EU), Webber found that "virtually none of the schemes currently operating as 'voluntary return programs' from Europe meet the criteria for voluntariness" since migrants are not adequately informed about the conditions in their country of origin and because voluntary returns are generally offered by the deporting country "as a less painful alternative to continued destitution followed by (inevitable) compulsory return" (2011). In other instances, migrants are escorted out of the country and through the international air transit system by CBSA guards trained in use of force techniques, demonstrating the varying biopolitical stakes of different configurations of the deportation passage.

While a significant portion of both voluntary and escorted removals are conducted on commercial planes where deportees are intermixed with regular free-moving passenger flows, there are also cases in which migrants are removed from the country on specially chartered deportation flights. These more exception removals make up the most opaque, costly and forcible of expulsions. In such cases, the entirety of the aircraft cabin 
is reconfigured into a mobile zone of detention: a carceral space in the sky in which migrants are directly under the watch of immigration enforcement officials and their partners in the aviation industry. Recent years have also seen the emergence of new forms of charter flight removal. Although removal operations carried out in chartered vehicles have typically involved only one or two deportees, Canadian authorities have more recently begun experimenting with mass removals and joint multi-state deportations. A phenomena which Miller and Youssef have termed 'collective expulsions' (2013), which have become routinized in the US, the UK and throughout the EU.

I also argue that the rise of air deportation has led to the emergence of new forms of anti-deportation resistance. While migrants and their allies have historically resisted removals using a variety of tactics and rationales, the normalization of air-based removals has created new ways for migrants to assert their agency and determine their own personal migration trajectories in defiance of restrictions constructed against their mobility. Notably, many of these acts of contestation target the very contingencies and vulnerabilities of the deportation flight. Also evident is that tactics of resistance against air deportation have emerged in an international context, with knowledge being shared by migrants and their allies across borders. While individual and group anti-deportation campaigning is typically carried out by migrants and allied activists, these actors are not the sole source of resistance to Canadian removal practices. According to documents released by GAC, "challenges to removal" include uncooperative clients, requirements of foreign governments, commercial airlines, medical conditions, and restrictions at transit points (2015b). Transportation companies and foreign countries have therefore also been 
known to intervene in the enforcement of Canadian deportations, demonstrating their capacity to exercise resistance to Canada's deportation regime.

This chapter will proceed with a few conceptual notes describing the specificities of air deportation and the ways in which this modality of state-led forced migration has reconfigured the work of deportation in Canada and elsewhere. I then present a brief discussion of the bureaucratic and legal technologies foregrounding the removal passage. This section is then followed by a discussion of the geography of deportation in Canada and a description of how air deportation manifests in the Canadian context.

\subsection{Conceptualizing Air Deportation}

The use of air deportation as a state practice has become so entrenched that many removals systems are logistically reliant on its use. This state dependence on the air transport system for the purposes of removal is made especially visible in instances where there are logistical restrictions inhibiting the enforcement of a removal via air deportation. Take the example of a Mexican woman by the name of Aida Castilla Romero who was forced to resist her placement on a deportation flight in January 2016 on account of a rare lung condition impeding her ability to fly at high altitudes without a significant risk to her life. Since Romero's removal order was issued, the CBSA has run into an impasse enforcing her expulsion because of the logistical and practical complications of carrying out her removal by other means. The Canadian removal system's reliance on air deportation is further magnified by the fact that Romero is willing to leave Canada — she has even requested that the CBSA cooperate with the US to secure land passage to Mexico (Underwood, 2016). She has nonetheless been rendered 
undeportable because she cannot be removed by conventional methods. ${ }^{13}$ Her situation therefore exemplifies how ingrained air deportation has become in Canada's contemporary deportation system — an entrenchment so intensive that removal operations break down when expulsion via air is not an option.

In an unpublished work, Walters and I argue that the aircraft has become a key weapon of immigration enforcement on account of three distinctive features that distinguish it from forced transportation technologies commonly used in the past (2016). These features not only facilitate the work and logistical organization of expulsions, they have also historically contributed to deportation becoming normalized as a routine, relatively-humane and merely-administrative practice. I therefore argue that by sanitizing the removal passage, the routinized use of the aircraft in contemporary removals has contributed to the wide scale legitimation of state-led forced migration.

The first of these features relates to the ways in which the emergence of aviation technology in immigration enforcement has allowed state officials to assert a new form of control over geographic space (Walters and Muñoz, 2016). The aircraft not only transports free-moving migration flows from one end of the world to another, it also affords authorities the ability to forcibly displace migrants from their homes in Canada to wherever their deportation destination might be geographically located. While commercial removal flights typically follow set schedules developed by airline companies, charter deportation allows states to create brand new corridors connecting the country from which a migrant is being expelled to their destination point (Walters and Muñoz, 2016). In this way the work of deportation contributes to the creation of new

\footnotetext{
${ }^{13}$ I am unable to confirm whether Aida Castilla Romero remained in Canada at the time of writing.
} 
geographic passages, as territory becomes bridgeable through the establishment of new routes of forced mobility.

Second, air deportation allows for compressed transit time, permitting the removal passage to be navigated and completed at jet speed (Walters and Muñoz, 2016). No longer must a deportee be forcibly transported for days, weeks or even months for an expulsion to be enforced as was common when deportation systems relied on sail-based vessels and later railway networks and steamship technologies. A removal from Toronto to Hungary can be carried out on a 12 hour commercial flight, and expulsions to other top Canadian removal destinations such as Mexico can be enforced in an even shorter transit time.

The shortening of the removal passage not only makes maintaining a deportation system more feasible from a governmental standpoint, it also reduces rates of mortality. As was discussed in the last chapter, expulsions in the early years of European settlercolonialism and imperialism in North America were particularly violent because of their lengthy duration and the high levels of death that occurred while a removal was being realized. Individuals confined to the cramped bowels of a ship for weeks on end often succumbed to illness before arriving at their destination, a tragic event that simply does not occur as commonly in the present now that removals are quickly carried out using carefully-designed aircrafts.

Finally, the airplane has emerged as a key technology of immigration enforcement because it functions as a vehicle of mobile confinement par excellence (Walters and Muñoz, 2016). Once boarded, a migrants movements are easily restricted by the physical layout of the airplane cabin. Flying high above the ground at jet speed also limits a 
deportee's ability to escape. Use of aviation technology therefore makes individual deportations easier to monitor and enforce from a government perspective. Still, air deportation is not the sole technology of immigration enforcement used by state officials to carry out the expulsion of the undesirable. An entire bureaucratic and legal structure has emerged to distinguish between the admissible and the inadmissible. This system of categorization is used by state officials exercising sovereign discretion to decide who is permitted the right to remain in the country and who is rendered deportable. I will now turn to a discussion of the bureaucratic mechanisms that have been created in Canada to facilitate removals.

\subsection{The Bureaucratic Structure of Removals}

Contemporary processes of expulsion necessitate the maintenance of a comprehensive apparatus and logistical world of deportation, one designed specifically to survey, categorize, and channel migrants through the complex administrative, legal and physical infrastructure of immigration enforcement. These mechanisms function to legitimize deportation by providing it with a bureaucratic sheen, affording authorities the ability to further depict state-led forced migration as a merely administrative practice while disavowing its penal and coercive characteristics. The administrative and legal aspects of removal also discursively criminalize the unwanted and in doing so normalize what De Genova calls the illegalization of migrants and the subsequent construction of their deportability (2002).

Admissibility determination plays a significant role in the sorting process and is

therefore a key mechanism by which migrants become legible by officials as removable. Currently, migrants can be categorized as inadmissible under the Immigration and 
Refugee Protection Act (IRPA) for: non-compliance with any of the provisions of the IRPA, having an inadmissible family member, for misrepresentation, financial reasons, health grounds, lesser criminality, ${ }^{14}$ serious criminality, ${ }^{15}$ involvement in organized crime, human or international rights violations and security reasons (CIC, 2015b).

While government documents typically emphasize a focus on removing criminalized migrants and others deemed by authorities to represent a threat to national security or a danger to the public, around $90 \%$ of those removed from Canada are in actuality deported for non-compliance with the IRPA, a category used for individuals who have overstayed their visas, failed refugee claimants and persons who are caught working or studying without a valid permit (see Figure 4) (GAC, 2015b and CBSA, 2015a).

Removals By Cause

\begin{tabular}{|c|c|c|c|c|c|c|c|c|c|c|c|c|c|}
\hline Cases & 2004 & 2005 & 2006 & 2007 & 2008 & 2009 & 2010 & 2011 & 2012 & 2013 & 2014 & 2015 & Total \\
\hline Criminality - Lesser & 365 & 368 & 409 & 364 & 386 & 458 & 406 & 459 & 468 & 440 & 429 & 74 & 4,626 \\
\hline Criminality - Serious & 623 & 588 & 638 & 580 & 637 & 664 & 659 & 696 & 738 & 714 & 722 & 137 & 7,396 \\
\hline Financial & 21 & 23 & 24 & 17 & 13 & 12 & 11 & 17 & 15 & 11 & 16 & 5 & 185 \\
\hline Health & 19 & 19 & 11 & 15 & 21 & 36 & 24 & 10 & 16 & 12 & 25 & 1 & 209 \\
\hline Human Rights Violations & 4 & 5 & 9 & 6 & 3 & 7 & 3 & 7 & 6 & 7 & 8 & 1 & 66 \\
\hline Inadmissible family member & 176 & 134 & 141 & 181 & 148 & 373 & 276 & 140 & 100 & 107 & 79 & 13 & 1,868 \\
\hline Misrepresentation & 135 & 83 & 108 & 72 & 62 & 59 & 98 & 106 & 138 & 92 & 116 & 21 & 1,090 \\
\hline Non-compliance with the act & 10,818 & 10,056 & 11,300 & 11,245 & 11,553 & 13,185 & 13,869 & 14,238 & 17,418 & 14,055 & 11,044 & 1,689 & 140,470 \\
\hline Organized crime & 19 & 10 & 18 & 25 & 19 & 67 & 41 & 31 & 48 & 39 & 47 & 6 & 370 \\
\hline Security grounds & 4 & 3 & 4 & 1 & 7 & 3 & 4 & 8 & 6 & 12 & 9 & & 61 \\
\hline Removal Cause & 12,184 & 11,289 & 12,662 & 12,506 & 12,849 & 14,864 & 15,391 & 15,712 & 18,953 & 15,489 & 12,495 & 1,947 & 156,341 \\
\hline
\end{tabular}

Figure 4-Removals by Cause, 2004-2015 (CBSA, 2015a)

In comparison, between 2004 and 2015, only 5\% of all migrants removed were deported for serious criminality, criminal association or security reasons. Under the Faster Removal of Criminals Act, individuals categorized as these inadmissibility types are denied the right to appeal their admissibility decision and can be removed even if they

\footnotetext{
${ }^{14}$ E.g. offences resulting in a criminal sentence less than 6 months, such as shoplifting.

${ }^{15}$ E.g. offences resulting in a criminal sentence longer than 6 months.
} 
have already served their criminal sentence (CBSA, 2014a), leading some to contest the removal of criminalized persons as 'double punishment' (Yiu, 2013).

Certain nationalities have also been rendered more deportable than others for individuals who apply to be admitted into Canada through the refugee determination system. Individuals from nation-states deemed by the Minister of Immigration, Refugees and Citizenship to be designated countries of origin (DCO) are less likely to be granted refugee status if they claim asylum in Canada. Refugee claimants from these countries are also processed at a greater speed than other claimants and these measures are in place to reduce the time and effort taken by government workers to review claims thought likely to be categorized as unfounded (CIC, 2016). Asylum seekers from DCOs are also denied the right to contest a negative decision on their claim to the Refugee Appeal Division and do not qualify for a work permit while they wait for their cases to be processed.

While many of the countries designated as safe are nation-states known to produce low levels of asylum seekers (typically countries from the Global North), the inclusion of countries such as Mexico and Hungary on the list, which produce high levels of refugees fleeing violence and marginalization, has been widely-critiqued by migrant justice activists as discriminatory (Fiallos, 2014). Activists have also critiqued the emergence of the Canada- US Safe Third Country Agreement (STCA) which immediately illegalizes most asylum seekers who transit through or live in the US before arriving to Canada (NOII- Toronto, n.d.). Both the DCO list and the STCA have been used by immigration authorities to discipline potential migrants to Canada from entering 
the country and to render deportable many of those who do succeed in crossing the border.

Once an individual is deemed inadmissible they can be issued a removal order and added to the CBSA's removal inventory. However, the CBSA can only enforce the removal once the migrant has exhausted all legal processes at their disposal that would allow them to remain. There are three major types of removal orders in Canada, each with incrementing degrees of severity. Departure orders stipulate that migrants must leave the country within 30 days of receiving notice. If they choose to remain or do not confirm their departure with an immigration official before leaving Canada, they can be disciplined by having their departure order escalated to a deportation order, which prohibits migrants from ever returning to Canada without first applying for an Authorization to Return to Canada document in addition to other necessary documentation. The severity of an exclusion order lies somewhere between that of a departure order and a deportation order. Migrants issued an exclusion order are prohibited from returning to the country for one to two years but once that time has passed they can re-enter without having to apply for authorization to return. This incremental approach to immigration enforcement demonstrates the ways in which Canada's deportation system is structured to penalize migrants who resist their forced expulsion and in this way deter others who might similarly wish to contest their deportation by remaining within Canadian territory.

In cases where a migrant is perceived by immigration enforcement authorities to be of risk, the CBSA can also exercise powers of detention which enable officials to forcibly detain migrants if they are considered by the state to be a flight risk, a danger to 
the public, wanted for international and/or human rights violations, or if the migrant's identity is viewed as suspect by immigration officials (CIC, 2010). The threat of detention is therefore a key way by which migrants are policed and disciplined into abiding to both visa obligations and removal orders, since resistance can lead to forcible incarceration without charge and other punitive outcomes.

\subsection{The Geography of Canada's Removal System}

The distribution of Canada's immigration enforcement network reflects the geographic contingencies of the Canadian landscape. Inland immigration enforcement authorities operate across a vast, sparsely-populated North American territory and are concentrated in a few densely-populated hubs that are well-connected to the international air transport system. This distribution of immigration enforcement exists in sharp contrast to geographies of removal in the past, when deportees were commonly channeled through Canadian cities with extensive access to maritime navigation routes. The physical layout of the Canadian territory likewise has important implications for how the work of deportation is carried out. Illegalized migrants removed from the far reaches of the Canadian landscape must commonly transit from capillary CBSA regions to enforcement hubs with extensive air transit connections for their removal to be enforced. This portion of the removal passage is commonly enforced via air when it is necessary to bridge considerable distances, which again stands in contrast to past geographies of removal reliant on railway networks. Canada's shared border with the US also has significant implications for how removals are realized by immigration officials, as some migrants removed to the US can be deported by road vehicles at land ports of entry. 
Until October 2009, Canada and the US had a Reciprocal Agreement which allowed Canadian enforcement officials to remove migrants holding nationality from a third country to the US if that person had been there prior to entering the country and vice versa (CBSA, 2015b). The US would then proceed to remove the migrant to their deportation destination on behalf of Canadian authorities. The STCA also allows for similar outsourcing practices: if a migrant crosses the border from the US and makes a refugee claim in Canada they can be returned to American immigration enforcement (CBSA, 2015b). Although these practices point to the relevancy of land-based deportation in Canada, air deportation nonetheless remains the most common modality of removal since aviation technology is often necessary to remove migrants anywhere beyond the US.

Documents released by the CBSA suggest the importance of five distinct CBSA regions in the realization of the immigration enforcement program (CBSA, 2012b). These 'enforcement centres' are responsible for carrying out the CBSA's national mandate on a regional scale. The work of deportation itself is consequently affected by regional contingencies specific to each enforcement centre despite efforts by CBSA national headquarters to promote consistency across the country (OAG, 2008). ATI disclosures from GAC also indicate the recent development of a centralized Removal Centre created specifically to coordinate the removal program on a national-level with a focus on criminal deportations (GAC, 2015b).

The geographic location of the five major CBSA regions is reflective of the densely-populated parts of Canada where migrants are mostly likely to settle, namely the Greater Toronto Area, the Quebec region, the British Columbia region, the Prairies and 
the Ottawa area. While there are smaller CBSA regional offices in other parts of Canada (such as the Atlantic region) these five areas play a significant role in the removal process as they have higher deportation volumes, contain a larger concentration of CBSA officers and also take on additional functions depending on the strategic value afforded by their geographic location as seen by the CBSA.

Corresponding with its significant foreign-born population, the Greater Toronto Area removes the greatest volume of individuals a year (around 6000 or $40-50 \%$ of the national total) and $46 \%$ of these migrants are expelled to destinations in the western hemisphere with another 24\% removed to European locations and 19\% to Asia (CBSA, 2012b). ${ }^{16}$ The region's strategic value to the CBSA lies in its access to the Pearson International Airport, an international aviation hub and the busiest airport in Canada. The large concentration of immigration enforcement activities has also allowed the Toronto enforcement centre to emerge as sort of experimental region for the CBSA. Numerous CBSA pilot projects have been tested in the GTA, such as the Assisted Voluntary Return and Reintegration Program (AVRR) run in partnership with the International Organization for Migration (IOM) and the Toronto Bail Program.

Another CBSA region that plays a strategic function in the immigration enforcement program is the Ottawa area. While only around 300 removals originate from this region in a year, CBSA offices in Ottawa play an important role within the program by liaising with foreign embassies located within the capital to secure travel documents for removals and to facilitate transit to deportation destinations (CBSA, 2012b). Detained migrants may also occasionally be taken to Ottawa by the CBSA to meet with

${ }^{16}$ These numbers were reported in a document dated 2011. 
representatives of their country of origin in order to secure documents or confirm their identity.

The Quebec region, which is concentrated around Montreal, has the second largest deportation volumes after Toronto with approximately 3600 removals a year (CBSA, 2012b). Most of these removals are to destinations in the Americas $(60 \%)$, Africa and the Middle East (27\%) and to Europe (26\%) (CBSA, 2012b). The British Columbia region is responsible for another 1300 removals a year and most of these deportations are destined for the Americas (48\%), Asia (22\%) and the US (16\%). The Prairie region, dispersed most prominently in Edmonton, Calgary, and to some extent Winnipeg, enforces around 600 removals a year and is also one of the regions with the highest expenses as deportees must commonly transit through other regions before arriving at their final departure point from the country (CBSA, 2012b and CBSA, 2015i). $58 \%$ of removals from the Prairies are bound for the Americas, with 20\% of deportees being removed to Asia and 14\% to Africa and the Middle-East (CBSA, 2012b).

Since Canada's top immigration source countries include nation-states such as the Philippines, India, China, Iran and Pakistan (CIC, 2015c), it is telling that most removals from Canada are destined for locations in the Western hemisphere, indicating that Canada's geography of removal is not reflective of present-day incoming migration flows. Instead, other factors such as undesirability seem to play a larger role. The top five removal destinations in FY 2013/2014 were the United States, Hungary, Mexico, Colombia and China (CBSA, 2015b).

The geographic location of the CBSA's three Immigration Holding Centres are another strong indicator of the physical distribution of Canada's removal architecture and 
they also point to the centrality of air deportation in the Canadian context given their proximity to major international airports. These migrant detention centres are located in three of Canada's largest cities, namely Toronto, Montreal and Vancouver. The detention centre in the Vancouver region is actually located within the Vancouver International Airport and the detention facilities in Toronto and Montreal are located near the Pearson International Airport and the Trudeau International Airport, respectively.

In parts of Canada without dedicated migrant detention facilities, migrants are typically detained in provincial prisons. They can also be kept in prison without charge if they are deemed by the CBSA to be too risky to be held in formal Immigration Holding Centres or if these dedicated facilities are filled. The placement of migrants awaiting removal in jails across the country affords added significance to forced air travel within Canada as the CBSA must use transportation escorts to move migrants closer to hub regions with international airports when their deportation becomes enforceable.

Take the example of an immigration enforcement-related operation that occurred on January $12^{\text {th }}, 2008$, when the CBSA chartered an Evas Airlines private plane to transport three detainees in Atlantic Canada to the Toronto region (see Figure 5). ${ }^{17}$ The first migrant was picked up in St. John's, NL along with two CBSA officers. The chartered aircraft then

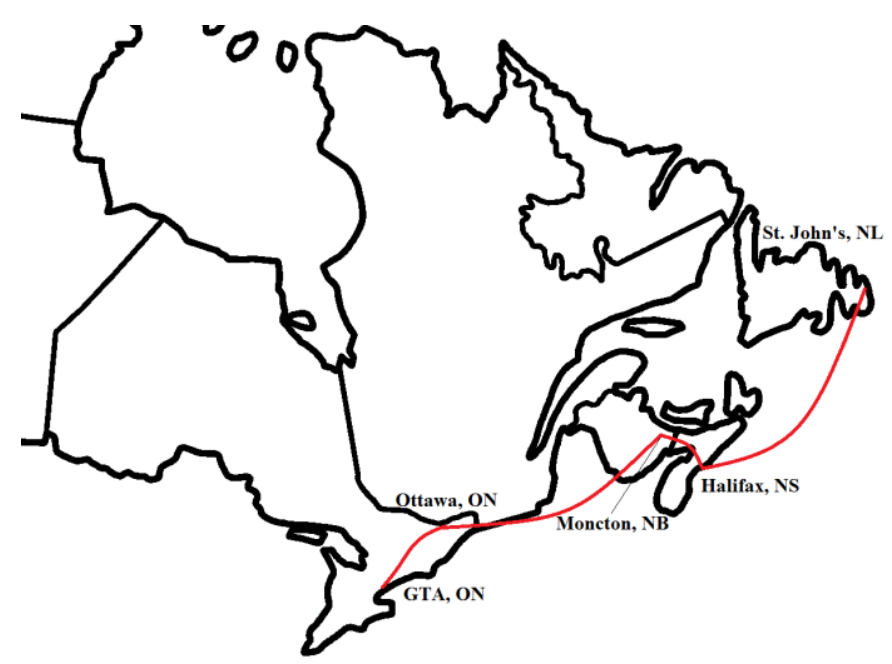

Figure 5-Evas Airlines Interregional Deportation Flight, 12 January 2008 (CBSA, 2009b)

${ }^{17}$ Figure is a geographic approximation. 
flew to Halifax, NS, where a second deportee was picked up along with two more CBSA escorts. A third stop was made in Moncton, NB, where yet another deportee boarded the deportation flight. The plane would fly to Ottawa for gas before arriving at the 'Million Air' Fixed Base Operation at the Buttonville Airport in the GTA (CBSA, 2009b). The immigration enforcement flight can therefore be described as having transited from a CBSA capillary region to the Toronto enforcement hub, from which the migrants were likely removed to their respective deportation destinations using the Toronto region's considerable air transit connections.

\subsection{Airmode Removals and the Logistics of Expulsion}

There are two major modalities of enforcement for removal operations within Canada. The first are removals carried out 'voluntarily' by the migrant subject to deportation. These 'voluntary' expulsions can be further differentiated into three distinct sub-categories, namely removals carried out with the 'voluntary compliance' of the migrant being deported, removals financed by the Canadian state and voluntary expulsions carried out as part of the AVRR program. While it is important to question the levels of agency extended to migrants who choose to 'voluntarily' comply with their removal orders given the dual threats posed by the immigration enforcement system of detainment and having a departure or exclusion order upgraded to a deportation order, those who do choose to leave the country following the requirements stipulated by the CBSA are nonetheless extended the ability to blend in with regular passengers unaccompanied by CBSA officers. Migrants who finance their own removal, which is categorized by the government as 'voluntary compliance,' are also granted the ability to schedule their own departure, even if it is within a narrow 30 day timeframe (CIC, 2010). 
Removals categorized as being carried out by the Minister (or Canadian state) can also be enforced with some degree of migrant agency. Unescorted removals are expulsions paid by Canadian authorities for migrants considered 'low-risk' (CIC, 2010). Although the state pays for the removal and schedules the time and place of departure, migrants are able to move relatively freely while in transit and can intermix with regular air passenger flows similar to those who choose to finance their own expulsion. However, to return to Canada once other requirements have been met, deportees expelled by the Minister must reimburse Canadian authorities for the cost of their removal (at a cost of $\$ 1,500)$.

Another type of 'voluntary removal' that emerged briefly in the Canadian context were expulsions enforced through the AVRR Pilot Project. From a viapolitical standpoint, the configuration of AVRR schemes is unique because state-funded deportees are granted the ability to blend in anonymously with other air passengers in a way that allows deportations to occur with minimal visibility, unlike other forms of 'voluntary' removal in which airlines are notified of a migrant's deportee status. The IOMadministered AVRR program in Canada ran from June 2012 until March 2015, and was structured similarly to AVRR schemes in other parts of the world, including countries such as the UK and Germany.

Commonly considered a more humane and dignified alternative to normalized deportation practices (IOM, 2015), AVRR programs provide refugee claimants who abandon their claims or are denied status with free airfare and financial assistance to facilitate their return and reintegration into their home country or another location where they are admissible. 3, 146 migrants were removed from Canada through the AVRR 
scheme in the first two years of the program (CBSA, 2015b), mostly to destinations in Hungary (48\%), Colombia (9.2\%), Croatia (5.2\%), Czech Republic (4\%), the Slovak Republic (3.7\%) and to some extent Mexico (CBSA, 2014b).

Before its cancellation, the AVRR pilot project was subject to high levels of criticism from all sides of the political spectrum. Anti-immigration advocates claimed that it was too expensive and that it predominantly functioned to give free air travel and money to 'bogus refugees' from safe countries, since four of the program's top five removal destinations were categorized as safe DCOs (Levitz, 2015). Meanwhile, migrant justice activists argued that the AVRR program was being used by immigration officials to misdirect asylum seekers into abandoning processes to appeal negative decisions on potentially valid refugee claims, because the program was structured to give migrants less money depending on how many appeal processes they initiated to try to remain in Canada (Cain, 2014a). AVRR removals can therefore be understood to be somewhat coercive as they provide migrants threatened with deportation with a false choice rather than true agency. In the end, the CBSA claimed that the project was too expensive to maintain. A report released by the CBSA through the ATI process comments that "senior officials like[d the program] but they d[id not] want to pay for it" (CBSA, 2013a).

One of the main ways migrants have resisted their voluntary or unescorted expulsion is to go underground. For example, in August 2014, Chilean Hector ReyesHidalgo defied his removal order by not presenting himself at the airport for his deportation flight to Chile. Reyes-Hidalgo had originally arrived in the country to visit and care for his mother, Julia Hidalgo-Aguillera, who has ALS (Feith, 2014). He remained in the country to continue being her caregiver. 
In another instance of contestation dating back to 2011, Iranian national and refugee claimant to Canada Masoud Hajivand thwarted expulsion after his arrival to Canada without valid documents by likewise failing to present himself at the airport. However, Hajivand was shortly thereafter disciplined by being detained without charge by the CBSA as a flight risk. He has since resisted deportation twice more. In 2014 he resisted by clinging onto the bars of his jail cell until six CBSA officers gave up on attempting to drag him out to transport him towards a deportation flight. Hajivand's third resistance to a scheduled expulsion took place on 18 September 2014 at the jail cells located within the Pearson Airport when he slit his wrists to avoid being forcibly boarded onto a deportation flight to Iran where he feared he might be subject to imprisonment, torture and possible execution (Cain, 2014b). Had he been removed, Hajivand would have likely been deported with an escort.

There are two distinct types of escorted removals in Canada, namely

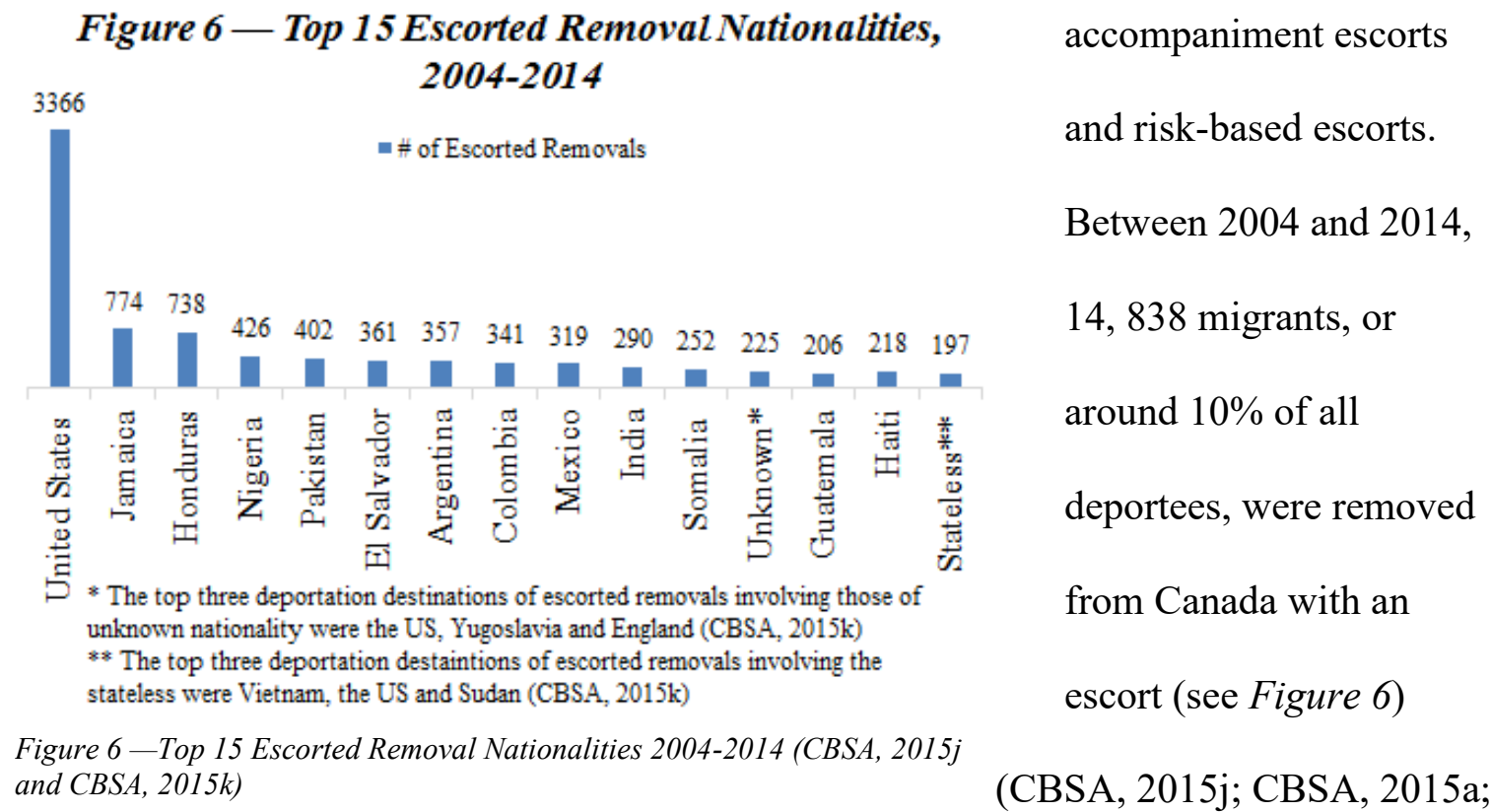

and CBSA, 2015k). This form of expulsion is amongst the most forcible and violent types 
of deportation experienced by unwanted migrants in the contemporary Canadian context. Escort officers are trained and have the authority to use force on the deportees under their watch when they deem it necessary to secure the migrant's compliance during the removal process. Individuals escorted out of the country are therefore commonly removed in handcuffs and shackles can be restrained more forcibly and subdued at the escort officer's discretion (Pratt, 2005). There are also reports dating back to the 1990s of sedatives being used on deportees to knock them out during the removal passage, thus shedding additional light on the corporeal brutality of some removal operations (Pratt, 2005). The presence of escorts therefore further curtails a migrant's agency since resistance to deportation can be met with significant physical retaliation.

Escorted removals also create significant logistical burdens for the CBSA. When realizing its escort function, the agency must not only pay for and schedule air travel for the deportee, it must also coordinate and finance the itinerary of its escort officers, who are unable to address their regular work obligations while they are removing someone abroad (CBSA, 2010). Furthermore, the work of physically enforcing a removal requires officers to acquire special training, and in practice, also challenges the deportation system's depiction as a peaceful administrative process.

Accompaniment escorts are typically used when the migrant under removal is a minor or when there must be a CBSA presence during the expulsion due to airline, transit country or destination country stipulations (CBSA, 2012b). Accompaniment escorts may also be used if the CBSA anticipates that problems will be encountered during the removal passage as is occasionally the case when the migrant is being removed without a widely recognized travel document. A 2003 evaluation of the Canadian immigration 
enforcement program states that "many people claiming refugee status destroy their documents $[\ldots]$ before their first contact with a Canadian official” (OAG). Desperate asylum seekers without valid documentation may also use forged documents or misrepresent their identity to gain access to the country. These actions of defiance can be described as anti-deportation tactics because a migrant cannot be forcibly returned through the air transit network without documentation, meaning that the CBSA is unable to immediately remove a migrant if they do not have a valid passport on their person. Destroying travel documents, or arriving without valid documentation, is therefore a key way in which asylum seekers can avoid or delay their removal while officials confirm the migrant's identity and acquire the documentation necessary for the expulsion. Although immigration authorities have responded to this anti-deportation tactic with a number of enforcement strategies of their own, including having airlines carry records of their passengers' documentation and immediately detaining those who arrive without adequate documents as flight risks, arriving without documents is nonetheless an act of resistance that can be used by the most desperate and vulnerable of refugees to buy themselves time to contest their inadmissibility determination and assert their right to remain. This is especially true for asylum seekers likely to be immediately found inadmissible and returned on 'same day removals' upon arriving at a Canadian airport.

In instances where the CBSA is unable to acquire a passport for a deportee, the agency occasionally uses a Canada Immigration Single Journey Document to secure air passage (CIC, 2010). However, this document is not universally recognized as legitimate. The CBSA must consequently accompany a deportee who is using this document or other 
questionable travel documentation if it is suspected that issues will arise at transit points or at the deportation destination.

Take the case of the Canadian deportee known as 'the man with no name,' who the CBSA attempted to remove to Guinea with escorts in 2013. Upon arrival, Guinean officials refused to admit the migrant into the country claiming that he did not have adequate documentation, evidencing the ways in which foreign governments can resist Canadian deportation practices (Humphreys, 2013a). CBSA presence was therefore required so that the 'man with no name' could be returned to Canada following the failed deportation.

Accompaniment escorts are also required for security reasons when a migrant being removed with a single journey document is transiting through "a strategically important hub or connection point (in particular London, Paris, Amsterdam, Zurich, Frankfurt, Rome, Port of Spain, Lima, Singapore, Hong Kong and the USA)” (CIC, 2010). These strategically important places afford migrants under deportation another opportunity to thwart return to their perceived country of origin. For example, in 2013 Jama Warsame evaded his removal from Canada to Somalia, where he had never been, by getting the attention of a Dutch official in Amsterdam, a transit point in his scheduled removal passage. After claiming refugee status in the Netherlands, Warsame was transferred by the CBSA into Dutch custody (Sniderman, 2013).

Transit points have also been used by migrants within Canada to evade removal. In 2012, a migrant being expelled from Vancouver to Costa Rica resisted deportation by bolting to freedom in the Pearson Airport shortly after disembarking from the first leg of his scheduled removal passage. The CBSA had planned for accompaniment escorts 
contracted from a security company to meet the deportee in the terminal so that they could escort him to his connecting flight. The migrant took the opportunity presented by their late arrival to instead escape from the CBSA and go underground (Godfrey, 2012). Risk-based escorts are used by the CBSA when officials have "determined that sufficient risk exists to justify it" (CBSA, 2012b). Such cases commonly emerge when the person being expelled has been deemed inadmissible for serious criminality or other human rights or security-based grounds. Risk-based escorts may also be used to realize difficult deportations or affect other types of unusual removals. Medical escorts can likewise be considered 'risk-based' since they are used in instances where there is enough risk to the migrant's health during the removal passage for a medical presence to be required.

Escorted removals can be carried out on scheduled flights using commercial aircraft with other passengers onboard or on privately chartered deportation flights. When an escorted removal is enforced on a flight with other passengers, as is the most common case in Canada, the CBSA must follow guidelines created by the specific airline being used, the countries being transited through, the destination country, the international guidelines established by the International Air Transport Association (IATA) and those created by the International Civil Aviation Organization (ICAO). The sheer quantity of these various directives and policies point to the high level and hybrid nature of governmental control guiding individual removal operations and the management of state-led forced migration more generally in the international system. These guidelines and regulations are notable for the emphasis they place on discretion and minimizing the visibility of removal procedures when they occur within the reach of the public gaze. 
The IATA's guidelines provide biopolitical directions for the CBSA and immigration enforcement authorities from other countries to follow. For example, they stipulate that the "check-in and boarding of deportees should be as unobtrusive as possible and kept separate for the normal passenger process to the extent allowed by the existing airport facility" (IATA/Control Authorities Working Group [CAWG], 2010). The IATA/CAWG additionally encourages escorts to discretely pre-board deportees in advance of regular passengers and to avoid "drawing undo attention" to the deportee if they are physically restrained (2010). Furthermore, the IATA/CAWG asserts that escorts should be trained in use of force techniques, including restraining devices and potentially sedatives (2010). Canadian escort officers are also required to sit with deportees at the very rear of the plane and to ensure that they and the deportee "are the last passengers to disembark" (CIC, 2010). The CBSA's enforcement guide additionally states that escorting officers should secure a room in the airport terminal away from the public should transportation be delayed (CIC, 2010).

Despite the various directives in place to ensure the successful execution of deportation operations, migrants and migrant justice activists around the world have found numerous ways to resist deportations enforced aboard passenger removal flights. A key goal of these tactics is to increase the visibility of the removal, thus targeting the commercial vulnerabilities of the involved airlines. In Canada, groups such as Solidarité sans Frontières and NOII have used social media networks such as Twitter and Facebook to organize anti-deportation events targeting airlines such as airline phone-ins and airport demonstrations. For example, in October 2014, Solidarité sans Frontières urged allies to call AeroMexico to voice their disapproval of the deportation of an undocumented 
Mexican teen who was detained at a school in Quebec and scheduled for removal without his family who remained underground in Canada. The grassroots group also called on allies to phone the federal Ministers of Immigration and Public Safety, as well as the Quebec Ministers of Education and Immigration to stop the removal. Apart from the phone-in, Solidarité sans Frontières also organized an airport demonstration in front of the check-in area targeted at AeroMexico passengers to encourage them to stand up on the plane to prevent the flight from taking off as scheduled in solidarity with the Mexican teen (Solidarité sans Frontières, 2014). This tactic was encouraged since it occasionally leads to pilots kicking deportees off of flights to remain on schedule. Although antideportation campaigning was unsuccessful in this case, some airport demonstrations have resulted in temporary victories.

Consider efforts taken to prevent the removal of Kobra Natghi and her son from Vancouver to Iran in January 2003. The two were originally scheduled to be removed on an Air Canada flight taking off from the Vancouver International Airport alongside a third Iranian national. However, once aboard, the migrants were removed from the flight by the pilot because they began physically resisting the deportation in front of other passengers. CBSA officials then proceeded to escort Natghi and her companions through the airport. There they encountered a group of 30 migrant justice demonstrators who helped Natghi and her son temporarily escape by forcing themselves between the migrants and their CBSA escorts (CBC News, 2003).

In another case, anti-deportation activists from migrant justice groups and the Sikh community rallied together in front of the Vancouver International Airport to delay the deportation of Laibar Singh, a paralyzed refugee claimant from India. Around 1, 500 
supporters were present at the demonstration which took place on 10 December 2007 and together they were able to delay Singh's eventual removal by physically blocking CBSA access to the taxi cab he was in. Singh's scheduled deportation flight therefore took off without him onboard (NOII- Coast Salish Territories/Vancouver, 2007). He was afterwards relocated with the help of his allies to a sanctuary in a Sikh Temple in Abbotsford, BC. In the weeks that followed, solidarity demonstrations were held in Halifax, Fredericton, Quebec City, Montreal, Ottawa, Kingston, Peterborough, Toronto, Guelph, London and Vancouver/Surrey (NOII- Coast Salish Territories/ Vancouver, 2008a). Despite these campaign efforts, Singh was eventually removed from Canada over a year later when he surrendered himself to the CBSA stating that he was "no longer able to endure [the] state of limbo" imposed on him by the Canadian state (NOII- Coast Salish Territories/Vancouver, 2008b).

Charter flight escorted removals are less common in the Canadian context when compared to the US, the UK and the EU, and mostly occur on an infrequent, ad-hoc basis when considered necessary by the CBSA. According to documents released through ATI, "charter flights provide an alternative means of removing individuals who are unable to be removed on commercial flights due to uncooperative behaviour, criminality and/or security/danger concerns" (CBSA, 2009b). They also allow the CBSA to remove individuals using point to point routing instead of relying on the hub and spoke system of typical commercial air travel. Removal passages therefore tend to be more direct in comparison to commercial flight transportation and allow the CBSA to create new routes to bridge the geography between the Canadian landscape and removal destinations. 
In practice, charter flights also afford officials the ability to effect expulsions with almost total secrecy as migrants are often boarded at smaller airports or at private hangers away from public terminals, allowing the work of deportation to be carried out with near invisibility. Another interesting aspect of this type of removal is that the vehicles and hangers used are most commonly reserved for the very wealthy, namely those who can afford to charter a private jet. Deportees are therefore removed in highly luxurious conditions when their expulsion is effected by charter.

While most charter deportation flights in Canada carry around one or two deportees, there are also examples of mass charter flight removals occurring in the Canadian context, including in partnership with other countries. Collective expulsions, be they coordinated by a single state or by multiple states in a joint operation, are reminiscent of the extremities of past collective removals carried out by boat. They are also the type of removal most emblematic of the violence of contemporary expulsion practices as they magnify the coercive aspects of removing entire groups of unwanted populations against their will without leaving a significant trace.

Mass removals carried out by a single state are used most commonly in countries with higher volumes of deportation such as the US, the UK, and other countries in the EU. In these contexts, they are predominantly used when there are enough deportees of a single nationality, or of a few countries that are closely located, to fill a chartered plane. Migrant justice activists in Europe have responded to these practices by organizing boycotts of the airlines most implicated in collective expulsions. For example, in Spain migrant justice activists have called for a boycott of Air Europa, the airline company 
holding a $€ 12$ million a year contract from Spanish immigration authorities to carry out charter flight removals (CECCIE, 2014).

Although they are less common in Canada, evidence of mass charter flight removals does exist in the Canadian context. One such instance occurred in Canada in 2000 when immigration enforcement officials removed a group of 90 Chinese nationals. These families and individuals had attempted to arrive to Canada by boat but were intercepted by authorities before they could reach the country's western shores. According to Mickleburgh, the mass charter removal was "conducted under heavy secrecy and security that included a police riot squad" and a canine unit (2000). After being awoken by guards at $1 \mathrm{am}$, the deportees were brought to the small Abbotsford Airport in British Columbia by bus from a jail in Prince George. Numerous migrants resisted their removal and were therefore transported with handcuffs. One Chinese migrant held in detention prior to the deportation also attempted suicide before the mass removal, demonstrating the severe consequences associated to the violence of the expulsion process (Mickleburgh, 2000).

Interestingly, Mountz discusses that one of the major reasons why the Chinese migrants were deported en masse was due to pressure from Chinese authorities who had indicated to Canadian officials that they would not issue travel documents to the migrants unless Canada agreed to repatriate an entire boatload of them at once. Chinese officials wanted to pursue this mass charter deportation flight tactic in order to send a "forceful public message that these were not in fact Convention refugees fleeing persecution [...] but rather economic migrants who had left China for opportunistic reasons" (Mountz, 2010). For Mountz, the use of chartered aircraft therefore served to homogenize the 
experiences of the migrants onboard, while aiding to craft a narrative about bogus refugees in which Canada was seen as an enforcer of the international refugee regime and China was depicted as an "innocent bystander" (2010).

Similar to mass charter flight removals, joint removal operations are likewise more common in regions with greater expulsion volumes and have become popular particularly in the EU where joint charter deportations are regularly coordinated by Frontex, the EU-wide immigration enforcement body. Although joint deportations no longer appear to be commonplace in the Canadian context, Canada and the US carried out joint expulsions together from 1999 until the practice was suspended in the late 2000s (Customs and Immigration Union, 2010). One of these joint removals occurred on December $16^{\text {th }}, 2006$, when a charter flight took off from Buffalo, New York bound for Nigeria and Liberia with escorts and detainees from both Canada and the US on board. 8 of the 99 deportees on the flight were removed from Canada and all of these migrants were being transported to Nigeria (NOII - Coast Salish Territories/Vancouver, 2006). In another instance, Canada paid US authorities $\$ 24,000$ USD for five one way removal tickets for Nigerian nationals who were expelled aboard an American deportation flight in 1999 (Pratt, 2005). Pratt further documents that Canada conducted 15 charter flight removals in 2003 to remove 130 "high risk or uncooperative individuals", and that 7 of these charter flight removals were carried out in partnership with the US (2005).

Despite the CBSA's decision to no longer carry out joint removals in 2008, recent documents released through the ATI process indicate that the Agency is reassessing its position as joint expulsions are thought to "produce significant cost savings and operational efficiencies" in the deportation process (CBSA, 2013a). Following this logic, 
in 2013 the CBSA considered, and may have participated, in a joint removal operation to Nigeria with both the US and the UK with the intention of removing 35 Nigerian nationals from Canada (CBSA, 2013a). Documents released through ATI do not confirm whether Canadian authorities went through with this operation. However, in international settings such as the Five Country Conference, Canadian representatives have expressed a commitment to enforce joint removals with close state allies, pointing to the willingness on the part of Canadian immigration officials to normalize the use of this removal tactic (CBSA, 2013a). Documents released by GAC also indicate that the CBSA is currently negotiating with the US to establish a joint air charter removal program (GAC, 2015b).

\subsection{Conclusion}

This chapter has provided a description of air deportation as it manifests in Canada given the region's geographic characteristics and expulsion techniques. It has also discussed the bureaucratic and legal mechanisms that are used by immigration officials to illegalize migrants and construct their deportability. In doing so, my aim has been to communicate a general overview of how state-led practices of forced migration materialize in Canada while focusing on the work of deportation conducted by state officials. The deportation system's reliance on aircraft technology and the international aviation network nonetheless implies the involvement of other actors in the removal passage. The following chapter will therefore focus specifically on third-party actors involved in what has been termed 'the migration control industry.' 


\section{Chapter 4: The Political Economy of Deportation in Canada: 'Doing more with less' and the Canadian Migration Control Industry}

\subsection{Introduction}

Maintaining a deportation regime requires significant public expenditures to finance the labour and training of human resources, the establishment of partnerships, the acquisition of equipment and other key expenses necessary for the functioning of a removal system. An internal study of the CBSA's escort function evaluating expenditures for 2010/2011 concluded that the estimated total cost of delivery for 'airmode' escorted removals that fiscal year, minus charter deportations, was $\$ 7.5$ million dollars, which included the cost of commercial airfare for 538 deportees and their escorts, salary and overtime expenses, and other officer-related expenses such as accommodation and incidental costs (CBSA, 2012b). The CBSA's Removals at a Glance documents also point to the hefty price tag of some individual removals: while the agency indicated in 2007 that the cost of a removal could be less than $\$ 100$ per deportee if affected at a land border with the US it also reported that a removal requiring the chartering of a private plane and the use of escorts could cost the Canadian government over \$1 million (CBSA, 2015b). ${ }^{18}$ These documents also price individual unescorted removals at $\$ 1,500$ and estimate that the average escorted removal typically costs the agency $\$ 15,000$ (CBSA, 2015b).

Overall in 2010/2011, the CBSA spent over \$91 million on immigration enforcement activities, including investigations, monitoring, detentions and removals

\footnotetext{
${ }^{18}$ Removals at Glance documents produced thereafter revise this initial figure to $\$ 500$ thousand and later
} $\$ 250$ thousand (CBSA, 2015b). 
(CBSA, 2012c). This expenditure resulted in the CBSA "removing a record number of inadmissible people (over 15,000)," in 2010/2011 (CBSA, 2011), a feat it surpassed in 2011/2012 when it spent approximately \$151 million on immigration enforcement and then again in 2012/2013 (CBSA, 2012c), when immigration enforcement costs totalled over $\$ 150$ million (CBSA, 2013b). To put these figures into perspective, within that same three-year time period, CIC's total expenditure on Canada's Refugee Program totalled just around \$176 million (CIC, 2011; CIC, 2012; and CIC, 2013), suggesting that Canadian officials prioritized removing asylum seekers over resettling refugee claimants (see Figure 7).

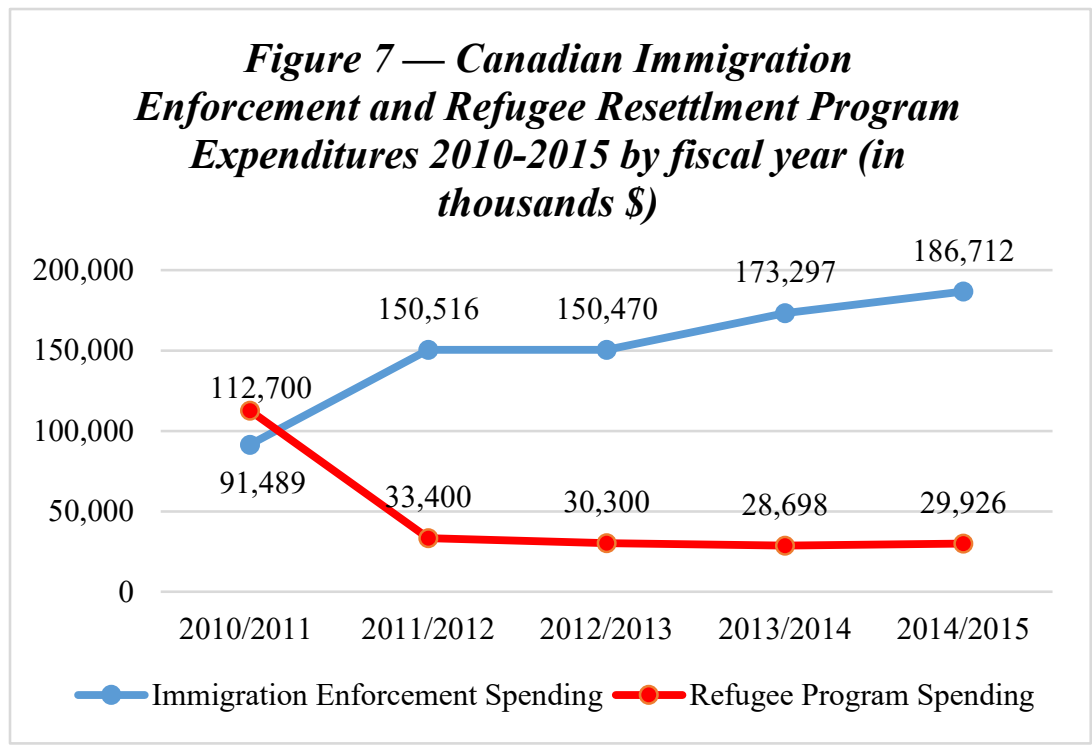

Figure 7 - Canadian Immigration Enforcement and Refugee Program Expenditures 2010-2015 (CBSA, 2012c; CBSA, 2013b; CBSA, 2014c; CBSA, 2015l; CIC, 2011; CIC, 2012; CIC, 2013; CIC, 2014; and CIC, 2015d))
Although these

overall expenditures are small in comparison to highercapacity deportation systems like those operated by the US and across the EU (ICE, 2016 and Journalism++, 2015),

they nonetheless demonstrate that the cost of removing someone against their will is not cheap, a concern which has led the CBSA to explore new ways to cut down on removal expenses. To realize these objectives of doing more with less and increasing the efficiency of removal operations, the Canadian government has begun experimenting 
with a number of measures intended to reduce, outsource or recover the costs of removals, while enabling the CBSA to continue deporting large quantities of individuals to destinations around the world. In light of these trends, this next chapter focuses on the political economy of air deportation while highlighting two major forms of public-private partnerships that have emerged within Canada's contemporary removal system.

The first of these partnerships involves the aviation industry. As has been discussed, contemporary removals as they exist today would be impossible without the airplane and without the various infrastructures and frameworks in place allowing these vehicles to fly through national and international airspace and land at airports or nodal points forming part of the worldwide air transport network. While partnerships between Canada's immigration enforcement authorities and the aviation industry can take on a variety of forms, some of these arrangements are characterized by greater levels of liability and penalty than others, which see Canadian immigration removals as a potential source of business. As such, it is possible to speak of the strengthening and growth of what Gammeltoft-Hansen terms 'the migration control industry' in the Canadian context (2013). The involvement of this industry in Canadian removal operations extends beyond the aviation sector to include a number of private deportation businesses - namely 'fixers' and private security companies who carry out aspects of the CBSA's removal function on behalf of or in collaboration with immigration officials.

\subsection{A Few Additional Concepts}

A few conceptual notes merit closer attention before moving forward with the empirical components of this chapter. Firstly, in referring to the political economy of deportation, I adopt a Foucauldian-inspired approach to analyzing state-led practices of 
removal. For Foucault, the study of political economy emerged in the $18^{\text {th }}$ century as an intellectual instrument by which the excesses or shortfalls of government could be measured, thereby making it "possible to gauge the rationality of governmental practice" (2008). Through this lens, political economy is understood to reflect on the effects of government action, more specifically on whether they are positive or negative, without considering these practices through a legal framework concerned with right or wrong (Foucault, 2008).

While there are significant limitations to analyzing air deportation from this somewhat bloodless vantage point, especially given the controversial nature of expulsions historically, the adoption of a Foucauldian political economic lens nonetheless provides an opportunity to temporarily restrict value judgements related to the general legitimacy of removals and instead focus on whether the work of deportation as it has existed in the recent Canadian context extends beyond the limits of rational governance. This is particularly relevant in the Canadian example due to the drastic increase in the number of deportations (and removal expenditures) a year between 2003 and 2013, many of which relied on deportation flights to effect territorial displacement from the Canadian landscape. Such an approach is also timely given statements made by whistleblowers formerly employed by the CBSA who have claimed that Canada's immigration enforcement system is operated by “orchestrated mismanagement” (Humphreys, 2014).

Given limitations inherent in Foucauldian approaches to political economy, I also enhance my analysis in this chapter by incorporating a discussion of states and illegal practices (Heyman and Smart, 1999). According to Heyman and Smart, considering the ways in which "governments and illegal practices enjoy some variety of symbiosis [...] 
enables us to transcend the [...] assumption that states always uphold the law" (1999). While most removal operations are carried out well within recognized legal parameters, other more exceptional removals involve blatant illegalities. Recall Saeed Jama's deportation to Somalia: the former Canadian refugee was smuggled into the country without documents with the help of an airline and the Kenyan government at a cost of $\$ 25,000$ in cash from CBSA representatives, a highly controversial arrangement at best. In a government commissioned 1996 evaluation of the removals program, Tassé also hinted at the existence of some illegal practices within Canadian immigration enforcement. In the final report he mentions that "during [his] discussions [with immigration enforcement officers] there were some unsubstantiated references made, in general terms, to alleged actions by some removal officers which, if true, could, depending on the circumstances of the case, involve a breach of the law" (Tassé, 1996). Qualifiers aside, this finding affirms that certain questionable practices have become entrenched within Canada's immigration enforcement system, and that they have been a part of the functioning of the deportation apparatus for quite some time.

The third concept I will discuss relates to the business activities that have emerged around the work of deportation. Gammeltoft-Hansen highlights the ways in which immigration enforcement operations have become increasingly privatized in the last ten year period (2013). This privatization trend has resulted in the emergence of what he describes as "a distinct migration control industry," an economic sector highly involved in the work of deportation across western states, including in Canada (Gammeltoft-Hansen, 2013). For Gammeltoft-Hansen, the rise of this industry has reconfigured practices of state sovereignty with key implications for the ways in which 
deportation is carried out (2013). While states remain in power in the sense that their agents retain the sovereign authority to decide who remains and who is expelled, physical control over migrant detainees is increasingly left in the hands of third-party actors, resulting in greater levels of hybridity within immigration enforcement operations.

According to Gammeltoft-Hansen, the outsourcing of removals and other elements of deportation such as detention is commonly justified by state officials "on grounds related to efficiency and better service" (2013) ${ }^{19}$ He nonetheless contends that partnerships with the private sector have proven themselves to undermine human rights, state obligations towards asylum seekers and public oversight over contentious and possibly illegal practices. This is because outsourcing allows controversial aspects of immigration enforcement to occur "behind a corporate veil, creating an 'out of sight, out of mind' effect that $[\ldots]$ complicates [...] independent [public] scrutiny" of removal operations (Gammeltoft-Hansen, 2013). Moreover, a private contractor's primary goal of maximizing profits may come into conflict with or undermine the protection of migrant's rights (Gammeltoft-Hansen, 2013). Gammeltoft-Hansen further notes that "governments can, through privatization, avoid the ordinary checks and balances of a democratic system" (2013). While a state may face public pressure to remain accountability and open about its activities, privacy rights and confidentiality agreements afforded to private enterprise somewhat shield third party actors from public contestation. The Canadian case provides compelling evidence in support of Gammeltoft-Hansen's claims while also demonstrating the nuanced and multiplex relationship between immigration authorities and private actors involved in deportation.

\footnotetext{
${ }^{19}$ Despite trends towards the privatization of immigration detention and immigrant detainee transportation, escorted removals remain in the public domain in almost all countries with the exception of the UK.
} 
Lastly, I reassert, once again following the work of Walters, that during the $20^{\text {th }}$ century we can begin to speak of the governmentalization of deportation (2010). This trend, focused on making visible, assessing and adapting the 'conduct of conduct' related to the work of deportation is easily evidenced in the Canadian context by the proliferation of evaluations and studies aimed at increasing the efficiency and cutting the costs of removal operations initiated by Canada's immigration officials.

\subsection{Removals from Canada and the Aviation Industry}

I begin my analysis of the political economy of deportation in Canada with a discussion of the involvement of the aviation sector. Given the centrality of air deportation in modern removal systems, the aviation industry has become deeply entrenched in migration control operations around the world and therefore serves as a key partner for state immigration authorities. Certain aspects of this relationship have been detailed by scholars such as Gilboy (1997) and Bloom and Risse (2014) who have identified ways in which airlines work with immigration officials to interdict individuals likely to be found inadmissible before they enter into a state's territory. In Canada, as well as in many other jurisdictions, this collaboration is structured by a series of disincentives which have been created to discipline airlines into proactively cooperating in immigration enforcement.

Although the CBSA, in partnership with airlines and immigration officials from other states, typically aims to or has been able to intercept around $70 \%$ of individuals considered inadmissible before they reach Canada (raising concerns related to the principle of non-refoulement), around $30 \%$ of individuals with inadequate documents still manage to cross Canada's physical border in any given fiscal year (CBSA, 2008 and 
CBSA, 2016). These cases often result in airlines having to partially finance the CBSA's immigration enforcement practices through the payment of carrier sanctions. They are also required to collaborate with officials to remove those they transport into the country.

If an individual is denied entry to Canada while attempting to clear Customs and Immigration at an airport, the airline who transported them can be held liable to pay a $\$ 3200$ 'administrative fee' to the CBSA. This fee is intended to recover the CBSA's costs in examining, detaining and processing the migrant and can be reduced anywhere between $25-100 \%$ if the airline is part of a Memorandum of Understanding Program run by immigration authorities (CIC, 2010). It is through this cost recovery mechanism that the CBSA has attempted to outsource some of the costs of deportation onto transportation companies.

Transportation companies are also held responsible for 'holding' suspected inadmissible persons while the CBSA completes its admissibility examination and must therefore provide facilities at the (air)port of entry until a decision is made by immigration officials. If the migrant is found to be inadmissible and not allowed to legally enter Canada, the airline also becomes liable for removing them (CIC, 2010). Airlines are therefore largely responsible for carrying out returns involving migrants who may have reached Canadian airports, but are nonetheless denied entry into Canada.

In an attempt to clarify airline liability requirements, organizations such as the United Nation's International Civil Aviation Organization (ICAO) have differentiated between 'inadmissible persons' and 'deportees.' The ICAO classifies inadmissible persons as those denied entry into a state, while deportees are migrants who legally enter a country and are afterwards slated for removal (2015). Within this framework, the 
removal of inadmissible persons is the responsibility of the air carrier while states are responsible for removals involving deportees (ICAO, 2015). There is nonetheless considerable overlap between deportations and inadmissible removals as defined by the ICAO in the Canadian context.

In Canada, migrants who are “denied a visa [or travel authorization], refused entry to, or removed from Canada" are all categorized as 'inadmissable' (CIC, 2015b). If they can be linked to a deportee, airlines are also liable "to carry from Canada any inadmissible foreign nationals they transported to Canada," regardless of how much time has passed since the individual first entered the country (CIC, 2009). These policy arrangements allow Canada to further 'outsource' some of the work of deportation to liable airlines as they are held responsible for making and covering the cost of removal arrangements to 'return' deportees from wherever they may be situated in the country.

The outsourcing of removals to airlines can be costly for carriers to absorb. For example, from September 2013 to August 2014, Air Canada removed 216 inadmissible persons at its own expense for $\$ 874,000$, without including the costs of same-day or nextday removals as these statistics are not tracked (Air Canada, 2015). Carrying out these removals also required the airline to at times lease private charter planes in cases where individuals were uncooperative, highlighting the similarities between removals affected by airlines and those enforced by the state (Air Canada, 2015).

Due to high costs and security concerns, airlines involved in the forced return of migrants may at times serve as unwilling participants in the state's immigration enforcement operations. Not only are the costs of detention and deportation downloaded onto these transportation companies, to reserve a seat for deportees, airlines must also 
forego the potential gains of having a paying passenger aboard their flight. Walters has additionally noted that being held liable for removals may also result in negative public attention potentially damaging to an airline's commercial interests (2010). Airline customers on business trips or enroute to vacation destinations may not wish to share a flight with someone resisting deportation or visibly being removed against their will.

For this reason, certain airline companies have publically resisted the extent of their involvement in the Canadian deportation regime. At the forefront has been Air Canada, which in 2015 made a formal submission to the Government of Canada's Review of the Canada Transportation Act to voice some of its concerns regarding the downloading of immigration enforcement onto air carriers. As part of its submission, Air Canada recommended that "the Government of Canada bear the cost of returning the passenger" if they traveled to the country using valid documentation yet were found to be inadmissible upon attempting to enter Canada through the airport (Air Canada, 2015). The airline also voiced its concerns regarding the risks presented by deportees who physically resist their removal aboard airplanes filled with regular passengers, suggesting that the Canadian government should not download 'risky' removals to airlines as state officials are better equipped to handle the challenges and costs associated to these expulsions (Air Canada, 2015).

The work of deportation nonetheless provides ample business opportunities for a number of willing airlines, typically smaller transportation companies. Two such companies are Skyservice Aviation and African Express. Established in 1986, Skyservice Aviation initially entered the highly competitive Canadian airline market as a discount air service. It had two major subsidiary companies involved in air travel: the now defunct 
Skyservice Airlines, which focused on Canadian vacation air travel to the Caribbean, Mexico, Europe and Israel; and Skyservice Business Aviation, which continues to primarily offer luxury private charter planes for executive business travellers out of Toronto and Montreal.

In 2003, Skyservice Business Aviation entered into a supply arrangement and standing offer agreement with the Government of Canada to provide airplanes for "domestic and some international air charter services [...] on an 'as and when requested' basis" for work such as "geological and wildlife surveys, fire-fighting, passenger transport, med-evac, land inspection and search and rescue" (Public Works and Government Services Canada, 2016). The charter airline has since become one of the CBSA's key partners in carrying out difficult deportations abroad to places such as Rwanda, Chad, Vietnam, Haiti, Somalia, Albania and Jamaica, amongst other locations (CBSA, 2015m). According to the few documents available, the costs of chartering planes for specific removals to these destinations have ranged in price from $\$ 31,253$ to $\$ 221,416$ (CBSA, 2015m). These removals have also at times involved undocumented or stateless persons, deportees with significant health issues and individuals at-risk of torture upon arriving at their destination, prompting some anti-deportation groups to label the airline "Canada's torture taxi" (Toronto Action for Social Change, 2008).

One such deportation was the removal of former Somalian refugee to Canada Yassin Ibrahim. Ibrahim was originally incarcerated in Winnipeg in 2002 for involvement in a number of violent street crimes and gang-related activity. In 2008, the CBSA contacted Skyservice to organize a charter deportation flight for his removal to Somalia (CBSA, 2009b). The CBSA's initial intention was to remove Ibrahim via 
Nairobi to Kismaayo in the South of Somalia where he had a cousin waiting for him (Sanders, 2008). However, a few weeks before his eventual removal, the CBSA received word that the US had bombed areas in Southern Somalia prompting the agency to rethink its plans and organize a drop off in Puntland, northern Somalia via Dijibouti — this occurred without Ibrahim being informed (CBSA, 2009b and Sanders, 2008). On March 24, Ibrahim was stripped down, placed in a diaper, shackled and boarded onto a small private plane where a bag was placed over his head. Canadian authorities did not permit him to take any of his personal belongings, including money he had saved, a change of clothes and his identification documents. Ibrahim's 21 hour flight itinerary to the Puntland area included a stop in Toronto, where another detainee was picked up, followed by stops in St. John's, the Czech Republic, Cairo and then Dijibouti (see Figure 8). ${ }^{20}$ There, Ibrahim was handed over to a militia group that transported him on a small plane to Puntland (Sanders, 2008).

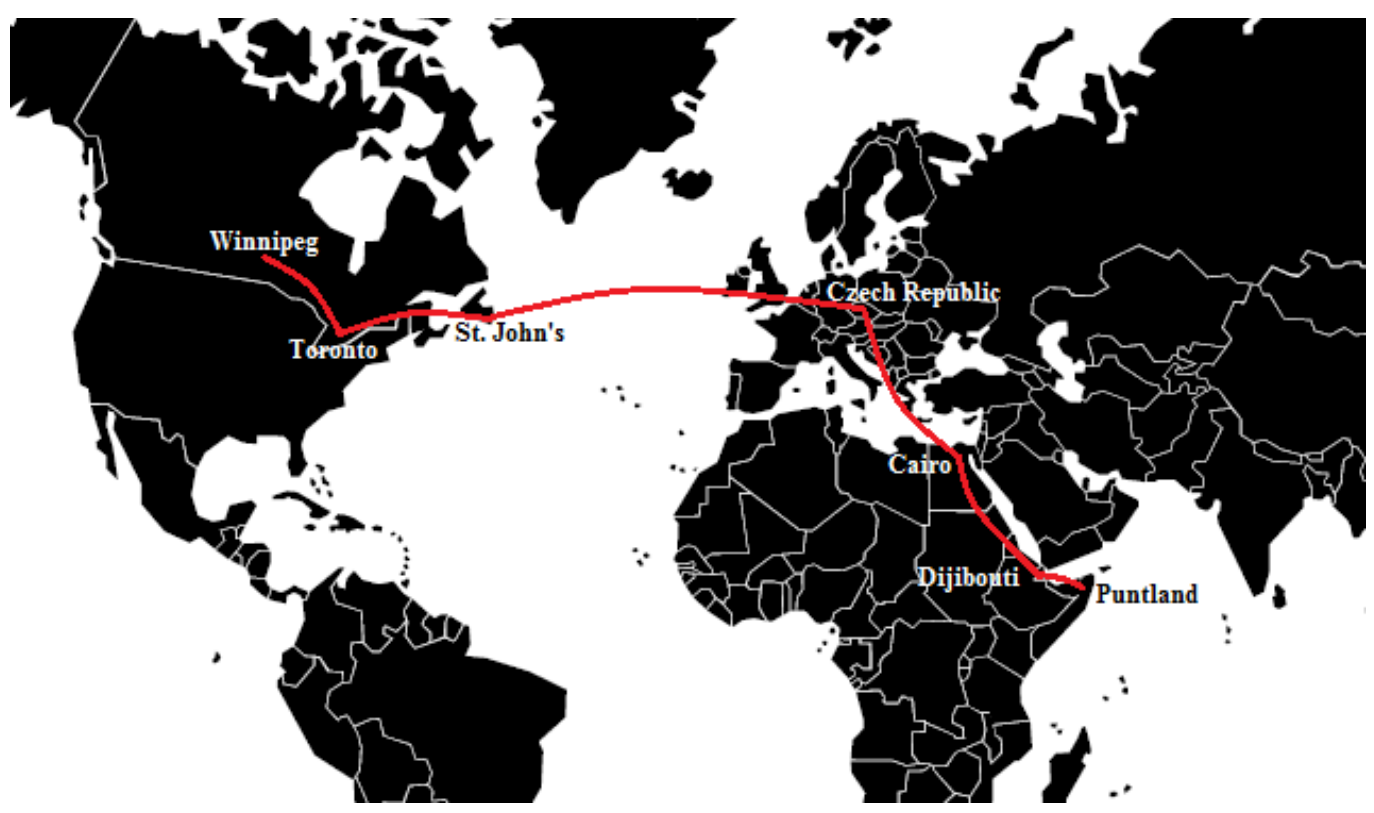

Figure 8 - Yassin Ibrahim's Deportation Passage (Sanders, 2008)

\footnotetext{
${ }^{20}$ Figure is a geographic approximation.
} 
According to Chipman, a small regional airline called African Express frequently partners with the CBSA to transport Canadian deportees during the final leg of removal journeys into Somalia (2015). Despite this collaboration and the regional airline's commercial interest in maintaining a working relationship with the CBSA, African Express has also been known to resist involvement in deportations which do not meet its airline requirements. Take the case of a Somalian refugee to Canada by the name of Abdirahmaan Warssama who was held in a Ontario provincial jail for over five years on an unenforceable deportation order because he refused to sign a piece of paper stating that he would cooperate with officials as they enforced the unescorted portion of his removal into Somalia aboard African Express. In response to Warssama's refusal to sign the consent form, African Express indicated to the CBSA that it could not return the deportee to Somalia. Warssama therefore remains in Canada and undeportable. He was released from immigration detention in January 2016 after his story became public (Keung, 2015).

Ibrahim and Warssama's experience with air deportation evidence how intrinsic airline partnerships are to the work of deportation in Canada. Companies like Skyservice and African Express not only benefit from the removal business offered by the CBSA, their transit requirements also have a direct impact on the CBSA's efforts to enforce contemporary expulsions. Ibrahim's deportation also demonstrates the hybrid nature of forced removals by exposing how other actors apart from the CBSA and the aviation industry have become involved in deportations. His expulsion to Puntland would not have been possible without the contributions of the militia group paid to smuggle him 
into Somalia. The discussion will now turn to these more legally suspect partnerships, namely those involving the use of what journalists have termed 'fixers' (Humphreys, 2013a).

\subsection{Fixers in Canadian Air Deportation}

Fixers can be described as private entities, be they individuals or for-profit organizations, which collaborate with immigration authorities to affect exceptional deportations using unconventional methods. These removals typically involve migrants who are difficult to remove due to a lack of documentation or due to other circumstances complicating Canadian official's ability to enforce their 'return.' For this reason, fixers occupy a controversial role in Canada's deportation apparatus and are used most commonly to carry out removal operations that the CBSA would otherwise be unable to attempt. These entities therefore profit from their involvement in some of the most opaque, dubious and forceful deportations coordinated under the auspices of the Canadian state.

For example, in the early 2000s, the Canadian Council of Refugees drew attention to the involvement of Protecting and Indemnity Associates International Ltd (P\&I), a South African security firm, in carrying out "three 'extremely difficult' removals of people from African nations ordered deported from Canada" (Freeze, 2001). The company in question had been chosen by Canadian officials to orchestrate these exceptional deportations due to its "expertise in African matters," a capacity obtained after conducting thousands of difficult removals in the region on behalf of other countries around the world (Freeze, 2001). 
Controversy over Canada's outsourcing practices with P\&I emerged after the details of one of these three removals came under public scrutiny. While two of the deportations had been enforced without any major obstacles, the third became increasingly complicated after the migrant was denied entry into his country of citizenship. The private security company therefore detained the migrant in Ivory Coast on behalf of immigration officials for the duration of about a month until he agreed to be removed to a third country instead of his original deportation destination. In response to the controversy generated, then-Minister of Immigration Elinor Caplan ordered the immediate cessation of immigration enforcement partnerships with fixers (Freeze, 2001). News of the involvement of fixers in difficult deportations has nonetheless continued to surface in subsequent years.

Canada's reliance on this type of for-profit deportation services came under major public scrutiny once again in 2013 following the CBSA's second attempt to deport a migrant called Michael Mvogo, who for a while was dubbed 'the man with no name' by the Canadian media (Humphreys, 2013a). The man with no name originally arrived in Canada via rail from the US using a forged American passport. After he was detained for participation in criminal activities, the CBSA attempted to return him to the US but was denied due to his lack of appropriate documentation. Mvogo would afterwards be held in non-criminal, administrative immigration detention in different Ontario jails for seven years during which he claimed numerous identities and nationalities (Humphreys, 2013a). At the time of Canada's second attempt to deport him, the CBSA had confirmed Mvogo's true identity through two retired teachers from Cameroon who had taught at schools Mvogo had previously attended (Humphreys, 2013b). Cameroonian officials were 
nonetheless sceptical of this identity claim and therefore refused to issue Mvogo a passport (Humphreys, 2013a).

Due to these numerous complications, the CBSA hired a Serbian fixer by the name of Ivan Simic to use his diplomatic connections to remove Mvogo from Canada to Guinea. Simic first used his relationship with Guinean officials to acquire a fraudulent passport claiming Mvogo was a Guinean citizen by the name of Michael Milimono. After the CBSA refused to use this travel document to carry out the deportation, Simic once again used his connections to secure Mvogo's passage to Guinea using a special single journey travel document issued by Guinean authorities at a price tag of $\$ 5000$. Mvogo was shortly thereafter flown to Guinea accompanied by Simic as well as two CBSA officers. At the airport, Mvogo was denied entry into the country by Guinean police officers who threatened to arrest everyone in the group due to the illegitimacy of Mvogo's travel documents. Mvogo eventually returned to Canada with the two escort officers and would remain in immigration detention until 2015 when he was finally granted passage into Cameroon (Humphreys, 2013a).

The National Post would go on to reveal that the CBSA had used Simic as a fixer to remove migrants to places such as Iran, South Africa, Liberia, Ivory Coast, Guinea and Cameroon (Humphreys, 2013a). Reg Williams, former Director of the CBSA's Greater Toronto Enforcement Centre, would also eventually lose his position at the CBSA over his role in the Mvogo incident. It nonetheless appears that the use of fixers to enforce difficult removals has become normalized by Canadian immigration authorities and may therefore remain a last-resort tactic to realize exceptional deportations. Other types of private deportation businesses are also commonly used to carry out less exceptional 
aspects of deportation in Canada. The involvement of these actors in the Canadian migration control industry may also expand in the near future as the CBSA pursues governmental processes to modify the work of deportation in order to cut down the cost of expulsions.

\subsection{The Privatization of Escorted Air Deportations in Canada}

Gammeltoft-Hansen asserts that once private enterprises become involved in activities associated to state sovereignty, their involvement typically continues to grow and becomes increasingly difficult to eradicate (2013). The use of private security service providers in Canadian immigration enforcement supports this argument. Private security providers Genesis, Garda Security and G4S currently hold contracts to operate Canada's immigration holding centres. These contracts include provisions to transport detainees between detention facilities, to appointments with doctors, meetings with immigration authorities such as the IRB, to land borders with the US to affect ground deportations and also between different regions of the country (CBSA, 2015d). For this reason, air-based intra-regional transfer of detainees typically involves private transportation escorts in areas of the country where their services are available, namely in Toronto, Montreal and Vancouver (CBSA, 2012b). One of the options that has been explored by the CBSA more recently in an effort to reduce the costs of deportation has been to expand the involvement of these contracted third party actors by privatizing escorted removals. Though rumours related to the privatization of Canada's removal escort function initially emerged in the late 1990s (Tassé, 1996), the CBSA has since its creation undertaken numerous governmental efforts to actualize this transfer of responsibility from the public sector to private industry. 
The privatization of the CBSA's escort function was first publically suggested in a 2010 internal evaluation study of the CBSA's immigration detention and removals program. Citing the need to cut costs and improve the efficiency of removals, the report proposed two separate alternatives to the status quo. The first alternative put forth was to create a special corps of CBSA officers specifically employed to carry out deportations. The CBSA's initial assessment of this option concluded that it was beneficial as it would allow the CBSA to remain in control of removals and provide escort officers with specific training and professional development opportunities while also permitting the agency to continue playing a diplomatic role overseas. However, the need to create a new position within the CBSA and the front-costs associated to establishing a dedicated corps of escort officers were seen as disadvantages (CBSA, 2010).

The second policy option put forth by the evaluation to increase the efficiency of Canadian removals was to privatize the CBSA's escort function in way similar to the UK (CBSA, 2010), which has used private security guards from G4S and more recently Tascor to carry out deportations beginning in the mid-2000s. The study indicated that an advantage of implementing the use of private escorts would be cost savings "due to lower wages, travel and overtime costs in the private sector" (CBSA, 2010). Disadvantages identified were that the CBSA could be held liable for the actions of private escorts, that guards would not have the same international recognition as CBSA agents and that low wages and possible high turnover could result in escorts of "variable quality" (CBSA, 2010). The CBSA's evaluation study concluded that a business-case analysis would be conducted in order to determine the feasibility of the options proposed, followed by the 
implementation of the best alternative if superior to the status quo as soon as possible (2010).

A few years later in 2015, a briefing note directed to the President of the CBSA indicated that an escort privatization pilot project was ready for procurement and subsequent implementation in the Toronto, Montreal and Vancouver regions (CBSA, 2015c). While my research findings are unable to confirm whether the privatization of the CBSA's escort function will in fact be implemented, the possible use of private contractors to carry out responsibilities typical of state sovereign and police powers raises concerns related to the treatment of deportees.

The privatization of immigration enforcement activities in both the UK and in Canada has resulted in numerous instances of abuse and illegality at the hands of private actors, hinting at the importance of adequate state presence in removal operations in any country where practices of expulsion have become normalized. The death of Jimmy Mubenga in the UK aboard a commercial deportation flight is a strong example.

Mubenga was being deported from the UK to Angola under private escort when he died on a British Airways flight about to take off from the Heathrow Airport. When he began resisting his removal, four G4S guards forced his head down despite Mubenga already being handcuffed from behind. Though Mubenga cried out stating that he could not breathe, the guards continued applying pressure and this use of force restricted his breathing leading to cardiac arrest. Following the fatality, the guards responsible were accused of manslaughter (though later acquitted) and a public inquiry was created to look into the conduct of private escorts when carrying out deportations. After these governmental processes were set in motion, a G4S whistleblower revealed that the 
company commonly allowed inadequately trained escorts to carry out removals which resulted in the frequent use of banned and potentially lethal restraint techniques, including the "carpet karaoke" restraint method that led to Mubenga's death. The whistleblower also revealed that a culture of racism and discrimination towards people of colour and vulnerable detainees was rampant amongst G4S employees. Numerous racist text messages sent by the guards charged with manslaughter provided proof of this second claim although this evidence was excluded from the trial (Lewis and Taylor, 2011).

Migrant detainees have also died while held by private guards in Canada. A case that garnered extensive media attention and public consideration was the death of Lucia Vega Jimenez while she awaited deportation at the immigration holding centre operated by Genesis Security at the Vancouver International Airport in 2013. This fatality also resulted in a public inquest. Though private guards are required to check on detainees every 30 minutes, inadequate monitoring, the common falsification of records, insufficient staffing levels and a lack of public and official oversight allowed Jimenez to commit suicide without guards noticing until after 40 minutes had passed. The inquest that followed revealed that private guards received minimal training to carry out their functions at the time of Jimenez's death. This training incorporated a single session with the CBSA which focused on shackling detainees. No emergency training or sensitivity training was included as is required for CBSA employees responsible for escorting detained migrants and working with vulnerable at-risk populations (Robinson and Carman, 2014). 
Though Jimenez was not under escort or active removal at the time of her death, her case nonetheless points to the significant and fatal disadvantages of subcontracting immigration enforcement activities to third party actors. Appropriately, the inquest following her death recommended that the CBSA cease outsourcing immigration enforcement work to these private security providers (Robinson and Carman, 2014). Efforts to outsource removals by privatizing escorted air deportation therefore run contrary to past Canadian experience. Also concerning is that companies like G4S and Genesis Security, which have been implicated in deportee deaths in the UK and in Canada, respectively, would be best positioned to win immigration escort contracts due to their current involvement transporting detainees within Canada and operating immigration holding centres in Toronto and Vancouver.

\subsection{Conclusion}

This chapter has provided an account of the political economy of deportation flights in Canada by discussing some of the public private partnerships that have emerged as part of the Canadian migration control industry. I focused specifically on third party actors implicated in the work of deportation under the direction of state immigration authorities. The rise of air-based transportation technology has led to the CBSA's governmental reliance on both forced and voluntary, for-profit cooperation from the aviation industry. Canadian immigration officials have also established costly partnerships with 'fixers' who have at times used extralegal methods to facilitate difficult removals involving stateless, document-less and other at-risk immigration detainees the CBSA would otherwise be unable to deport. The growth of the Canadian migration control industry and the governmentalization of deportation has additionally been 
demonstrated through a discussion of the CBSA's efforts to expand the involvement of private security providers in Canadian immigration enforcement operations through the privatization of escorted removals.

Past experiences demonstrate that the distancing of the public sector from the work of deportation in Canada and UK has resulted in the abuse and mistreatment of deportees while under the watch of private actors. These lessons caution against the use of private enterprise to carry out the removal function of Canada's immigration enforcement program. Of course, this is not to say that public actors are incapable of abuse and negligence. However, if deportations are to occur, escorts employed by the public sector and receiving extensive training are likely preferable over private escorts reputed to be of 'variable quality.'

An interesting feature of the Canadian context since $9 / 11$ has been the focus on expanding deportation capacity during periods of fiscal austerity. This has resulted in governmental attempts to recover and cut down costs while the immigration enforcement budget has been at a historic high, leading to greater levels of abuse in the enforcement of expulsions. While these patterns are once again changing as demonstrated by declining removal levels, the heightened deportation capacity of the Canadian state during the first ten years of the CBSA nonetheless functioned to reduce consideration of possible alternatives to deportation, such as regularization programs and preventive measures such as prioritizing investment in refugee resettlement. 


\section{Chapter 5: Conclusion}

It is my hope that this thesis has contributed to a greater understanding of a contentious and often overlooked practice carried out by the settler-colonial Canadian nation-state in partnership with international and private actors. While the media occasionally provides coverage of more exceptional and controversial cases of contemporary expulsion, the mechanics of state-led forced migration as it occurs in the Canadian context remains a relatively underexplored topic. This research has therefore sought to shed light on the logistical underpinnings of a removal system operating behind closed doors far from the public gaze, one which has undergone a number of recent transformations as a consequence of $9 / 11$, the creation of a new immigration enforcement body and the implementation of a governmental objective to drastically increase the number of removals in Canada a year during a period of fiscal austerity and cuts to refugee funding.

My adoption of a viapolitical approach to this study of deportation has also afforded me the ability to build on existing discussions of the Canadian deportation regime by highlighting the key roles that vehicles, routes and transportation systems of forced mobility play in Canada's current removal architecture. As a result, I have argued throughout this thesis that the rise and entrenchment of air deportation has fundamentally reconfigured the deportation passage in way that contributes to the sanitization and widescale legitimation of contemporary expulsions carried out under the auspices of the nation-state. While the majority of these expulsion practices are commonly accepted by the general public, others challenge the assumption that states always abide by the law. The normalization of air deportation has also led to the emergence of new actors in 
removal operations: some are unwilling participants while others are driven by profitincentives, enabling us to speak of the emergence of a distinct Canadian 'migration control industry' profiting from the business of air deportation.

I have complimented my use of a viapolitical approach to this research with the use of Foucauldian analytics and postcolonial theory. Foucauldian concepts such as sovereignty, discipline and governmentality have been incorporated because of their utility and explanatory power when applied to the phenomenon of deportation more broadly. Post-colonial theory has been used to highlight Canada's settler-colonial past and present, a dynamic not captured by viapolitics nor Foucauldian theory, which continually informs how expulsions are configured in the Canadian context.

In Chapter 2 I provided a brief literature review of existing scholarship documenting past expulsions that have occurred on lands now recognized as Canadian. I also sought to capture the differing viapolitical elements of these early removal passages. Doing so allowed me to demonstrate how removals occurring before the rise of air deportation are distinct from the removals of today while also asserting how this history of expulsion continues to inform deportations in the present.

The attempted forced removal of the Mi'kmaq, the expulsion of the Acadians, the return of Irish convicts from Newfoundland and the perceived and 'voluntary' repatriation of the Trelawny Maroons all evidence how expulsions were carried out by imperial and colonial authorities. Some of these removals occurred on foot while the majority relied on maritime transportation technologies of questionable sea-worthiness. I therefore argued that expulsion in these early years of colonization was punitive and characterized by long, cramped and often lethal removal passages. 
Following the settler-colonial rise of the Canadian nation-state, deportation power was formally incorporated as a tool of state-sovereignty — a disciplinary weapon usable by the state to assert discipline and governance over mobile populations. The removals of injured, destitute workers and political dissidents such as communists were used as examples in this thesis to demonstrate how the Canadian state has historically used deportation as a mechanism of social control. The removal from the Vancouver Harbour of the migrants aboard the Komogata Maru and the expulsion of Japanese-Canadians provided further examples of how immigration enforcement has historically been used to displace those considered 'undesirable' from Canadian territory. While many expulsions occurring after Confederation relied on upgraded maritime transportation technologies such as steamships, they also required the use of Canada's railway system to affect removal, resulting in a maritime and railway-centric geography of deportation.

In Chapter 3 I focused on the specificities of present-day deportations and described how contemporary state-led forced migration is vastly distinct from removals in the past. Although state-use of expulsions was once considered to be somewhat barbarous, the entrenchment of air deportation and the incorporation of the international aviation system into the architecture of removal has allowed state agents to quickly remove undesirable migrants from Canadian territory to wherever in the world they are considered admissible using the aircraft cabin as a space of mobile confinement.

Because of this arrangement, expulsions are no longer closely associated to punishment and death. The speed and relative comfort of the aircraft as compared to transportation technologies of the past has therefore contributed to the sanitization of present-day removals. Contemporary deportations nonetheless continue to discipline 
migrants illegalized through bureaucratic constructions of deportability and this coercive function becomes especially visible through the unpacking of different types of expulsions. While some removals afford migrants relative agency, others, especially those involving multiple deportees guarded by escorts trained in use of force techniques, challenge the deportation regime's depiction as a mere-administrative process by evidencing its more violent and disciplinary features.

The rise of air deportation has also shifted the Canadian state's geography of removal: expulsions are no longer channeled through rail networks and maritime navigations routes, instead, immigration enforcement is concentrated around denselypopulated regions with extensive access to the worldwide air transport system. Given Canada's widespread geographic distribution, aviation technology also helps to bridge the distance between different CBSA regions, facilitating the agency's capacity to funnel migrants out of Canada from wherever they may be situated in the country.

Chapter 4 of this thesis furthers my analysis of deportation flights in Canada by describing the involvement of third-party actors implicated in the contemporary Canadian deportation regime. The rise of air deportation has led to the emergence of new actors in immigration enforcement: fellow passengers, airline representatives and private deportation businesses can all be described as complicit in removals, demonstrating the hybrid nature of a deportation regime dependent on industry and international cooperation. Some of these actors are unwilling participants, while others such as charter airline companies, fixers and private security firms offering immigration enforcement escort services financially benefit from the work created by the Canadian immigration enforcement program. In many cases, the Canadian government has used these 
partnerships, or considered further normalizing their involvement, to facilitate difficult expulsions and to cut down the costs of deportations, raising ethical concerns about the transfer of responsibility from the public sector to private industry in coercive contexts such as state-led forced migration.

I have also provided examples of resistance to expulsions throughout the pages of this thesis. These acts of contestation not only include the efforts of migrants resisting deportation and their allies, but also those of transportation companies and foreign representatives with the ability to restrict the smooth execution of Canadian removals. Given the centrality of air deportation in Canada and elsewhere, I argued that efforts to resist removals commonly target the specific logistical and commercial vulnerabilities of the deportation flight.

Though these various findings are useful contributions to studies of deportation in Canada and research on the viapolitics of expulsion more generally, my experience researching air deportation in the Canadian context has nonetheless led to the conclusion that there are many more areas of research related to this topic that are worthy of future exploration. My work in this thesis has focused on describing and denaturalizing the logistical operations necessary to maintain a deportation regime. However, maintaining an ever-evolving removal apparatus is far from being the only or most logical policy option for states seeking to manage migration flows transcending its borders. Future research should therefore seek to identify alternatives to removal that allow migrants wishing to make a home on colonized lands to provide for their families and flourish within Canadian territory in a way respectful of the ancestral rights of those native to the landscape. Another potential direction could be to further explore how the Canadian 
state's recent prioritization of removals has contributed to the neglect of refugee and resettlement programs, leading to the increased marginalization and illegalization of vulnerable migrant communities within Canada. At the core of these studies should be a concern for the right to remain and wellbeing of migrants who live in defiance of borders. Their bravery challenges the enclosure of the global commons while disrupting the notion that something as natural as human migration can be effectively channeled, or disciplined into stasis. 


\section{Works Cited}

Adey, P. (2010). Aerial Life: Spaces, Mobilities and Affects. West Sussex: WileyBlackwell .

Air Canada. (2015). The aviation industry as an economic enabler: Air Canada submission to the review of the Canada Transportation Act. Air Canada.

Akins, T. B. (Ed.). (1869). Acadian heartland: records of the deportation and Le Grande Dérangement 1714-1768. Halifax: Nova Scotia Archives.

Ashworth, A., \& Zedner, L. (2010). Preventive orders: a problem of undercriminalization? In R. Duff, L. Farmer, S. Marshall, M. Renzo, \& V. Tadros (Eds.), The Boundaries of the Criminal Law. Oxford: Oxford University Press.

Ashworth, A., \& Zedner, L. (2012). Prevention and criminalization: prevention and limits. New Criminal Law Review: An International and Interdisciplinary Journal, 15(4), 542-571.

Augé, M. (1995). Non-Places: Introduction to an Anthropology of Supermodernity. London and New York: Verso.

Bannister, J. (1998). Convict transportation and the colonial state in Newfoundland, 1789. Acadiensis, 27(2).

Barker, V. (2013). Democracy and deportation: why membership matters most. In K. Franko Aas, \& M. Bosworth (Eds.), The borders of punishment: migration, citizenship, and social exclusion. Oxford: Oxford University Press.

Basok, T., Bélanger, D., \& Rivas, E. (2014). Reproducing deportability: migrant agricultural workers in South-western Ontario. Journal of Ethnic and Migration Studies, 40(9), 1394-1413.

Bauder, H. (2013). Why we should use the term illegalized immigrant. RCIS Research Brief, 2013(1).

Behrens, M. (2012). Taking liberties: Canada's booming business of detention and deportation. Rabble.ca.

Black, D. (2015). Big drop in deportations worries former Canada border agency executive. The Toronto Star.

Bleichmar, J. (2000). Deportation as Punishment: A historical analysis of the british practice of banishment and its impact on modern constitutional law. Georgetown Immigration Law Journal(14), 115-163. 
Bloom, T., \& Risse, V. (2014). Examing hidden coercion at state borders: why carrier sanctions cannot be justified. Ethics and global politics, 7(2), 65-82.

Blue, E. (2015). National Vitality, Migrant Abjection and Coercive Mobility: the Biopolitical History of American Deportation. Leonardo, 268- 269.

Brown, W. (2008). Regulating Aversion: Tolerance in the Age of Identity and Empire. New Jersey: Princeton University Press.

Cain, P. (2014a). Canada pays thousands of Roma to abandon refugee appeals, leave country. Global News.

Cain, P. (2014b). Iranian refugee's jail ordeal: 173 days and counting - with no end in sight. Global News.

Campaña estatal por el cierre de los centros de internamiento de extranjeros. (2014). Paremos los vuelos: las deportaciones de inmigrantes y el boicot a Air Europa. Oviedo: La Cooperativa.

Canada Border Services Agency. (2008). 2007-08 Departmental Performance Report. Ottawa: Government of Canada.

Canada Border Services Agency. (2009a). 2008-09 Departmental performance report. Canada: Government of Canada.

Canada Border Services Agency. (2009b). A-2009-00849. Released under the Access to Information Act . Ottawa: Government of Canada.

Canada Border Services Agency. (2010). CBSA Detentions and Removals Programs: evaluation study. Ottawa: Government of Canada.

Canada Border Services Agency. (2011). 2010-2011 Departmental performance report. Ottawa: Government of Canada.

Canada Border Services Agency. (2012a). A-2012-03217. Released under the Access to Information Act. Ottawa: Government of Canada.

Canada Border Services Agency. (2012b). A-2012-11710. Released under the Access to Information Act. Ottawa: Government of Canada.

Canada Border Services Agency. (2012c). 2011-2012 Departmental performance report. Ottawa: Government of Canada.

Canada Border Services Agency. (2013a). A-2013-05860. Released under the Access to Information Act. Ottawa: Government of Canada. 
Canada Border Services Agency. (2013b). 2012-2013 Departmental performance report. Ottawa: Government of Canada.

Canada Border Services Agency. (2014a). A-2014-13037. Released under the Access to Information Act. Ottawa: Government of Canada.

Canada Border Services Agency. (2014b). Evaluation of the Assisted Voluntary Return and Reintegration Pilot Program - final report. Ottawa: Government of Canada.

Canada Border Services Agency. (2014c). 2013-2014 Departmental performance report. Ottawa: Government of Canada.

Canada Border Services Agency. (2015a). A-2015-03765. Released under the Access to Information Act. Ottawa: Government of Canada.

Canada Border Services Agency. (2015b). A-2015-10302. Released under the Access to Information Act. Ottawa: Government of Canada.

Canada Border Services Agency. (2015c). A-2015-10289. Released under the Access to Information Act. Ottawa: Government of Canada.

Canada Border Services Agency. (2015d). A-2015-05590. Released under the Access to Information Act. Ottawa: Government of Canada.

Canada Border Services Agency. (2015e). A-2015-05600. Request under the Access to Information Act. Ottawa: Government of Canada.

Canada Border Services Agency. (2015f). A-2015-05596. Request under the Access to Information Act. Ottawa: Government of Canada.

Canada Border Services Agency. (2015g). A-2015-05594. Reguest under the Access to Information Act. Ottawa: Government of Canada.

Canada Border Services Agency. (2015h). A-2015-05595. Released under the Access to Information Act. Ottawa: Government of Canada.

Canada Border Services Agency. (2015i). A-2015-05598. Released under the Access to Information Act. Ottawa: Government of Canada.

Canada Border Services Agency. (2015j). A-2015-11953. Released under the Access to Information Act. Ottawa: Government of Canada.

Canada Border Services Agency. (2015k). A-2015-14222. Released under the Access to Information Act. Ottawa: Government of Canada. 
Canada Border Services Agency. (20151). 2014-2015 Departmental performance report. Ottawa: Government of Canada.

Canada Border Services Agency. (2015m). A-2015-05599. Released under the Access to Information Act. Ottawa: Government of Canada.

Canada Border Services Agency. (2016). 2015-2016 report on plans and priorities. Ottawa: Government of Canada.

Casas-Cortes, M., Cobarrubias, S., \& Pickles, J. (2015). Riding routes and itinerant borders: autonomy of migration and border externalization. Antipode, 47(4), 894914.

CBC News. (2003). Woman who bolted deportation found hours later. $C B C$.

Chipman, J. (2015, November 4). To No Man's Land . The Current.

Citizenship and Immigration Canada. (2009). Enf-15: obligations of transporters. Ottawa: Government of Canada.

Citizenship and Immigration Canada. (2010). Enf-10: removals. Ottawa: Government of Canada.

Citizenship and Immigration Canada. (2011). 2010-11 Departmental Performance Report. Ottawa: Government of Canada.

Citizenship and Immigration Canada. (2012). 2011-12 Departmental Performance Report. Ottawa: Government of Canada.

Citizenship and Immigration Canada. (2013). 2012-13 Departmental Performance Report. Ottawa: Government of Canada.

Citizenship and Immigration Canada. (2014). 2013-14 Departmental Performance Report. Ottawa: Government of Canada.

Citizenship and Immigration Canada. (2015a). A-2015-18595. Released under the Access to Information Act. Ottawa: Government of Canada.

Citizenship and Immigration Canada. (2015b). Reasons for Inadmissibility. Retrieved from Government of Canada:

http://www.cic.gc.ca/english/information/inadmissibility/who.asp

Citizenship and Immigration Canada. (2015c). Facts and figures 2014 - Immigration overview: Permanent residents. Retrieved from Government of Canada: http://www.cic.gc.ca/english/resources/statistics/facts2014/permanent/10.asp 
Citizenship and Immigration Canada. (2015d). 2014-2015 Departmental Performance Report. Ottawa: Government of Canada.

Citizenship and Immigration Canada. (2016). Designated countries of origin. Retrieved from Government of Canada: http://www.cic.gc.ca/english/refugees/reformsafe.asp

Collier, S. J. (2009). Topologies of Power: Foucault's Analysis of Political Government Beyond 'Governmentality'. Theory, Culture and Society, 26(6), 78-108.

Coulthard, G. (2008). Red Skin, White Masks. Minneapolis: University of Minnesota Press.

Cribb, R. (2015). Foreward. In J. Brownlee, \& K. Walby (Eds.), Access to Information and Social Justice: Critical Research Strategies for Journalists, Scholars and Activists (pp. vii-xiii). Winnipeg: Arbeiter Ring Publishing.

Customs and Immigration Union. (2010). Analysis of Canada Border Services Agency's proposed closure/reduction of service at land-border, other points-of-entry and points of service in Quebec, Ontario and Saskatchewan. Ottawa: Customs and Immigration Union.

De Genova, N. (2002). Migrant 'illegality' and deportability in everyday life. Annual Review of Anthropology, 31, pp. 419-447.

De Genova, N. (2010). The deportation regime: sovereignty, space and the freedom of movement. In N. De Genova, \& N. Peutz (Eds.), The deportation regime sovereignty, space and the freedom of movement (pp. 33-65). Durham and London: Duke University Press.

Dean, M. (2002). Powers of Life and Death Beyond Governmentality. Cultural Values, 6(1), 119-138.

Dow, M. (2007). Designed to Punish: Immigrant Detention and Deportation. Social Research, 74(2), 533-546.

Ekirch, R. A. (1985). The transportation of Scottish criminals to America during the 18th century. Journal of British Studies, 24(3), 366-374.

Ellermann. (2008). The limits of unilateral migration control: deportation and interstate cooperation. Government and Opposition, 43(2), 168-189.

Fairclough, N. (2001). Critical discourse analysis as a method in social scientific research. In R. Rudak, \& M. Meyers (Eds.), Methods of Critical Discourse Analysis (pp. 121-138). London: Sage Publications. 
Feith, J. (2014). Chilean man hiding from immigration authorities. Montreal Gazette.

Fekete, L. (2011). Accelerated Removals: The Human Cost of EU Deportation Policies. Race and Class, 89-97.

Fiallos, F. (2014). Harper government continues to ignore dangers in Mexico. Retrieved from Rabble.ca: http://rabble.ca/news/2014/12/harper-government-continues-toignore-dangers-mexico

Fife, R. (2016). Temporary foreign workers program faces federal review. The Globe and Mail.

Fortier, C. (2013). No One Is Illegal movements and anticolonial struggles from within the Nation-State. In L. Goldring, \& P. Landolt (Eds.), Producing and negotiating non-citizenship: precarious legal status in canada (pp. 274-290). Toronto: University of Toronto Press.

Foucault, M. (2008). The birth of biopolitics. In M. Senellarte (Ed.), Lectures at the college de France, 1978-79. Basingstoke and New York: Palgrave Macmillan.

Freeze, C. (2001). Activists slam private deportations. The Globe and Mail .

Gammeltoft-Hansen, T. (2013). The rise of the private border guard: accountability and responsibility in the migration control industry. In T. Gammeltoft-Hansen, \& N. Nyberg Sorenson (Eds.), The migration industry and the commercialization of international migration (pp. 128-151). London and New York: Routledge.

García Hernández, C. C. (2015). Creating crimmigration. BYU Law Review, 2013(6), 1457-1516.

Gibney, M. J. (2013). Is Deportation a Form of Forced Migration? Refugee Survey Quarterly, 32(2), 116-129.

Gilboy, J. (1997). Implications of 'third-party' involvement in enforcement: the INS, illegal travelers and international airlines. Law and Society Review, 31, 505-530.

Gill, N. (2013). Mobility Versus Liberty? The Punitive Uses of Movement Within and Outside Carceral Environments. In D. Moran, N. Gill, \& D. Conlon (Eds.), Carceral Spaces: Mobility and Agency in Imprisonment and Migrant Detention (pp. 19-36). Surrey: Ashgate Publishing Limited .

Global Affairs Canada. (2015a). A-2015-00946. Released under the Access to Information Act. Ottawa: Government of Canada. 
Global Affairs Canada. (2015b). A-2015-00953. Released under the Access to Information Act. Ottawa: Government of Canada.

Godfrey, T. (2012). Second illegal bolts to freedom . Toronto Sun.

Golash-Boza, T. M. (2015). Deported: immigrant policing, disposable labor and global capitalism. New York : NYU Press.

Gonzalez, R. J. (2012). Anthropology of the Covert: Methodological Notes on Researching Military and Intelligence Programs. Anthropology today, 28(2), 2126.

Goutor, D. (2007). Guarding the gates: the Canadian labour movement and immigration, 1872-1934. Vancouver: UBC Press.

Griffiths, N. E. (1992). The contexts of Acadian history, 1686-1784. Sackville: Centre for Canadian Studies Mount Allison University.

Haig-Brown, C. (2009). Decolonizing Diasphora: Whose Traditional Land are We On? Cultural and Pedagogical Inquiry, 1(2), 4-21.

Heyman, J., \& Smart, A. (1999). States and illegal practices: an overview. In J. Heyman (Ed.), States and illegal practices (pp. 1-24). Oxford and New York: Berg.

Hindess, B. (2000). Citizenship in the International Management of Populations. American Behavioural Scientist, 43(9), 1486-1497.

Humphreys, A. (2013a). Canada's bizarre — and failed — attempt to send 'the Man With No Name' to Africa and the mysterious fixer who made it happen. National Post.

Humphreys, A. (2013b). Canada relies on two retired Cameroon school teachers to test latest identity claim from 'Man With No Name'. National Post.

Humphreys, A. (2014). Canada's immigration enforcement system suffers from 'orchestrated mismanagement,' whistleblower claims. National Post.

International Air Transport Association/Control Authorities Working Group. (2010). Guidelines for the removal of deportees. Montreal: International Air Transport Association.

International Civil Aviation Organization. (2015). Annex 9 to the Convention on International Civil Aviation - Facilitation (14 ed.). Montreal: International Civil Aviation Organization. 
International Organization for Migration. (2015). Assisted voluntary return and reintegration. Retrieved from International Organization for Migration: http://www.iom.int/assisted-voluntary-return-and-reintegration

Jafri, B. (2012, March 21). Privilege Vs. Complicity: People of Colour and SettlerColonialism. Federation for the Humanities and Social Sciences . Retrieved from http://www.ideas-idees.ca/blog/privilege-vs-complicity-people-colour-and-settlercolonialism

Journalism++. (2015). The money trails. Retrieved from The migrant files: http://www.themigrantsfiles.com/

Kanstroom, D. (2007). Deportation nation: outsiders in American history. Cambridge and London: Harvard University Press.

Keung, N. (2015). Somali man ordered released after 67 months in immigration detention. The Toronto Star .

Kipfer, S. (2011). Decolonization in the heart of empire: some Fanonian echoes in France today. Antipode, 43(4), 1155-1180.

Kofahl, M. P. (2014). Trelawny Maroon, the colour of freedom: reconceptualizing subjecthood in the eighteenth-century Britist Atlantic. Halifax: Dalhousie University.

Landry, D. J. (1999). The Ships of the Acadian Expulsion. Retrieved from AcadianCajun Geneology and History: http://www.acadian-cajun.com/landryships.htm

Lawrence, B., \& Dua, E. (2005). Decolonizing antiracism. Social Justice, 32(4), 120-143.

Levitz, S. (2015). Ottawa to end contentious refugee return program . the Toronto Star.

Lewis, P., \& Taylor, M. (2011). Jimmy Mubenga: security firm G4S may face charges over death. The Guardian.

Line, D. (2014, November 8). The United States-Canadian Border: Undefended No More. The Economist.

Lockerby, E. (1998). The deportation of the Acadians of Ile St. Jean, 1758. Acadiensis, 27(2).

Lockett, J. D. (1999). The deportation of the Maroons of Trelawny Town to Nova Scotia, then back to Africa. Journal of Black Studies, 30(1), 5-14. 
Marsh, J. H. (2012). Japanese internment: banished and beyond tears. Retrieved from Historica Canada: http://www.thecanadianencyclopedia.ca/en/article/japaneseinternment-banished-and-beyond-tears-feature/

Marsh, J. H. (2013). the Deportation of the Acadians. Retrieved from Historica Canada: http://www.thecanadianencyclopedia.ca/en/article/deportation/

Martin, J. (1975). Convict transportation to Newfoundland in 1789. Acadiensis, 84-99.

McDonald, J. (2009). Migrant Illegality: Nation-Building and the Politics of Regularization in Canada. Refuge, 65-77.

Michalon, B. (2013). Mobility and Power in Detention: The Management of Internal Movement and Governmental Mobility in Romania. In D. Moran, N. Gill, \& D. Conlon (Eds.), Carceral Spaces: Mobility and Agency in Imprisonment and Migrant Detention (pp. 37-56). Surrey: Ashgate Publishing Limited.

Mickleburgh, R. (2000). Canada deports Chinese migrants en masse. The Globe and Mail.

Mignolo, W. (2006). Citizenship, knowledge and the limits of humanity. American Literary History, 312-331.

Miller, P., \& Shiar, Y. (2013). Collective expulsion: the case against Britain's mass deportation charter flights. London: Corporate Watch Co-operative Ltd.

Molinaro, D. (2010). 'A species of treason?': deportation and nation-building in the case of Tomo Čačić, 1931-1934. The Canadian Historical Review, 91(1), 61-85.

Molinaro, D. (2011). Deportation. Retrieved from Historica Canada: http://www.thecanadianencyclopedia.ca/en/article/deportation/

Monaghan, J. (2015). Four Barriers to Access to Information: Perspectives of a Frequent User. In J. Brownlee, \& K. Walby (Eds.), Access to Information and Social Justice: Critical Research Strategies for Journalists, Scholars and Activists (pp. 53-74). Winnipeg: Arbeiter Ring Publishing.

Moran, D., Piacentini, L., \& Pallot, J. (2013). Liminal TransCarceral Space: Prison Transportation for Women in the Russian Federation. In D. Moran, N. Gill, \& D. Conlon (Eds.), Carceral Spaces: Mobility and Agency in Imprisonment and Migrant Detention (pp. 109- 126). Surrey: Ashgate Publishing Limited.

Morgan, G., \& Rushton, P. (2013). Banishment in the Early Atlantic World: Convicts, Rebels and Slaves. New York: Bloomsbury. 
Mountz, A. (2010). Seeking asylum: human smuggling and bureaucracy at the border. Minneapolis and London: University of Minnesota Press.

Neilson, B., \& Rossiter, N. (2010). Still Waiting, Still Moving: On Labour, Logistics and Maritime Industries. In D. Bissell, \& G. Fuller (Eds.), Stillness in a Mobile World. London and New York: Routledge.

Neilson, B., \& Rossiter, N. (2014). Logistical Worlds: Territorial Governance in Piraeus and the New Silk Road. Logistical World: Infrastructure, Software, Labour, 5-10.

No One Is Illegal - Coast Salish Territories/ Vancouver. (2008a). Reportback: national days of action in support of Laibar Singh. Retrieved from No One Is Illegal Coast Salish Territories/ Vancouver: https://noii-van.resist.ca/?p=636

No One Is Illegal - Coast Salish Territories/Vancouver. (2008b). Update: Laibar Singh's 'return' to India. Retrieved from No One Is Illegal - Coast Salish Territories/Vancouver: https://noii-van.resist.ca/?p=917

No One Is Illegal- Coast Salish Territories/Vancouver. (2006). Joint U.S./Canada deportation - largest ICE deportation to Africa in 2 years. Retrieved from No One Is Illegal- Coast Salish Territories/Vancouver: https://noiivan.resist.ca/?p=210

No One Is Illegal- Coast/Salish Territories/Vancouver. (2007). 1500+ halt deportation of Laibar Singh at Vancouver International Airport. Retrieved from No One is Illegal - Coast Salish Territories/Vancouver: https://noii-van.resist.ca/?p=599

No One Is Illegal- Toronto. (n.d.). Refugee Process in Canada. Retrieved from No One is Illegal- Toronto: http://toronto.nooneisillegal.org/node/378

Nyers, P. (2010). Abject cosmopolitanism: the politics of protection in the antideportation movement. In N. De Genova, \& N. Peutz (Eds.), The deportation regime: sovereignty, space and the freedom of movement (pp. 413-431). Durham and London: Duke University Press.

Office of the Auditor General of Canada. (2003). Chapter 5-Citizenship and Immigration Canada - Control and Enforcement. In 2003 April Report of the Auditor General of Canada. Ottawa: Government of Canada.

Office of the Auditor General of Canada. (2008). Chapter 7: Detention and removal of individuals - Canada Border Services Agency. Ottawa: Government of Canada.

Office of the Information Commissioner of Canada. (2014). Annual Report 2013-2014. Ottawa: Government of Canada. 
Office of the Information Commissioner of Canada. (2014). Annual Report 2014-2015. Government of Canada.

Oikawa, M. G. (1999). Cartographies of violence: women, memory and the subject(s) of internment (doctoral dissertation). University of Toronto.

Parsons, C. (2015). Beyond ATIP: New Methods for Researching State Surveillance Practices. In J. Brownlee, \& K. Walby (Eds.), Access to Information and Social Justice: Critical Research Strategies for Journalists, Scholars and Activists (pp. 161-183). Winnipeg: Arbeiter Ring Publishing.

Paul, D. N. (2000). We were not the savages: collision between European and North American civilizations. Halifax: Fernwood Publishing.

Peutz, N., \& De Genova, N. (2010). Introduction. In N. De Genova, \& N. Peutz (Eds.), The deportation regime: sovereignty, space and the freedom of movement (pp. 129). Durham and London: Duke University Press.

Plank, G. (1996). Two majors cope: the boundaries of nationality in Mid-18th century Nova Scotia. Acadiensis, 25(2), 18-40.

Pratt, A. (2005). Securing Borders: Detention and Deportation in Canada. Vancouver: UBC Press.

Public Works and Government Services Canada. (2016). Skyservice business aviation daffaires inc (E60SQ-020001/042/SQ). Retrieved from buyandsell.gc.ca: https://buyandsell.gc.ca/procurement-data/standing-offers-and-supplyarrangements/E60SQ-020001-042-SQ

Roberts, B. (1988). Whence they Came: Deportation from Canada 1900-1935. Ottawa: University of Ottawa Press.

Robinson, M., \& Carman, T. (2014). Inquest jurors want upgraded holding centre, CBSA staffing. The Vancouver Sun.

Rudesch Harley, R. (2009). Around the World in 80 Airports. In S. Cwerner, S. Kesselring, \& J. Urry (Eds.), Aeromobilities (pp. 135-156). New York: Routledge.

Sanders, C. (2008). Should Somalia's anarchy rule out deportation? Winnipeg Free Press.

Simonsen, D. G. (2010). Space in Transit: Airplane Cabins and the Non-places of Supermodernity. Scandia, 74(2), 103-126.

Smith, A. (2013). Foreward. In H. Walia, Undoing border imperialism (pp. ix- xiii). Oakland: AK Press/Institute of Anarchist Studies . 
Sniderman, A. S. (2013). Jama Warsame is a citizen of nowhere. Macleans.

Solidarité sans Frontières. (2014). Stop the deportation of Montreal-area student. Retrieved from Solidarité sans Frontières: http://www.solidarityacrossborders.org/en/thursday-stop-the-deportation-of-amontreal-area-student-protest-at-montreal-airport

Stumpf, J. (2006). The crimmigration crisis: immigrants, crime, and sovereign power. American University Law Review, 56(2), 367-419.

Sunahara, A. G. (1981). The politics of racism. Toronto: James Lorimer and Company.

Taiaiake, A., \& Corntassel, J. (2005). Being Indigenous: resurgances against contemporary colonialism. Government and Opposition, pp. 597-614.

Tassé, R. (1996). Removals: processes and people in transition. Ottawa: Citizenship and Immigration Canada.

Timmons, D. (2011). "Evangelines of 1946:" the exile of Nikkei from Canada to Occupied Japan. Victoria: University of Victoria.

Toronto Action for Social Change. (2008). Skyservice: Canada's torture taxi? Retrieved from Justice for Mohamed Harkat :

http://www.justiceforharkat.com/news.php?extend.2911

U.S. Department of Homeland Security. (2016). Budget-in-brief: fiscal year 2016. United States : Government Printing Office. Retrieved from https://www.dhs.gov/sites/default/files/publications/FY_2016_DHS_Budget_in_B rief.pdf

UK Independent Advisory Panel on Non Compliance Management. (2014). Report of the UK Independent Advisory Panel on Non Compliance Management. United Kingdom : Crown Copyright.

Underwood, C. (2016). Mexican woman fears deportation flight could kill her. The $C B C$.

United Nations. (1963). Convention on offenses and certain other acts commited on board aircraft. Tokyo: United Nations.

Urry, J. (2009). Aeromobilities and the Global. In S. Cwerner, S. Kesselring, \& J. Urry (Eds.), Aeromobilities (pp. 25-38). New York: Routledge.

Valverde, M. (2007). Genealogies of European States. Economy and Society, 36(1), 159178. 
Velloso, J. G. (2014). Seeking alternatives for criminology: the Immigration and Refugee Board practices on the regulation of immigration in Canada. Ottawa: University of Ottawa.

Walby, K., \& Larsen, M. (2011). Access to Information and Freedom of Information Requests: Neglected Means of Data Production in the Social Sciences. Qualitative Inquiry, 18(1), 31-42.

Walia, H. (2013). Undoing Border Imperialism. Oakland: AK Press and the Institute for Anarchist Studies.

Walters, W. (2010). Deportation, Expulsion and the International Police of Aliens. In N. De Genova, \& N. Peutz (Eds.), The Deportation Regime: Sovereignty, Space and the Freedom of Movement (pp. 69-100). Durham and London: Duke University Press.

Walters, W. (2014). Migration, Vehicles, and Politics: Three Theses on Viapolitics. European Journal of Social Theory, 1-20.

Walters, W. (2016a). Aeroplanes and deportation. Zolberg Institute on Migration and Mobilities: 2015-2016 Lecture Series. New York City: The New School. Retrieved from https://www.youtube.com/watch?v=LZneSTRHfpE

Walters, W. (2016a). The Flight of the Deported: Aircraft, Deportation and Politics. Geopolitics, 1-24.

Walters, W., \& Muñoz, L. (2016). Air deportation: British and Canadian perspectives. unpublished ms.

Webber, F. (2011). How voluntary are voluntary returns? Race and Class, 52(4), pp. 98107.

Wright, C. (2013). The Museum of Illegal immigration: historical perspectives on the production of non-citizens and challenges to immigration controls. In L. Goldring, \& P. Landolt (Eds.), Producing and negotiating non-citizenship: precarious legal status in Canada (pp. 31-54). Toronto: University of Toronto Press.

Yiu, C. (2013). What is double punishment? . Retrieved from Solidarité sans frontières: http://www.solidarityacrossborders.org/en/solidarity-city/solidarity-cityjournal/what-is-double-punishment

Zilio, M. (2013). Deportee Says He was Smuggled In Disguise Through the Mogadishu Airport. Ipolitics. 